\title{
هفارقة التحضر: جدل النظام وفوضى العنف
}

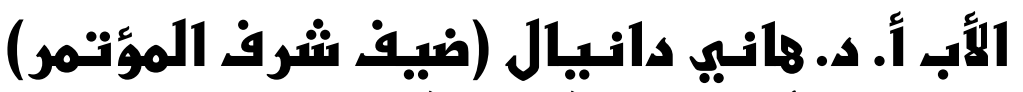 أستاذ الفلسفة الحديثة والمعاصرة رئيس قسم الفسفة بكلة بكلية بابل إربيل كوردستان - العراق يائ}

$$
\begin{aligned}
& \text { "أعتقد أن العنف أمر لا مفر منهه، }
\end{aligned}
$$

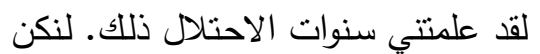

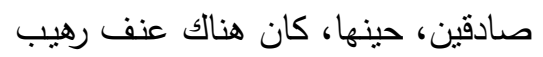

$$
\begin{aligned}
& \text { لم يسبب لي أي مشاكل. لن أقول، لذلانك، }
\end{aligned}
$$

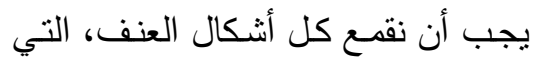

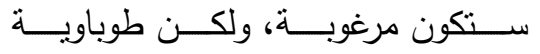

$$
\begin{aligned}
& \text { بالفعل. أقول فقط إنتا يجب إلب (utopique) }
\end{aligned}
$$

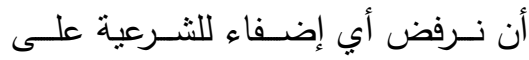

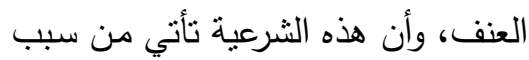

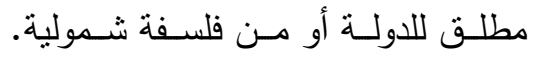

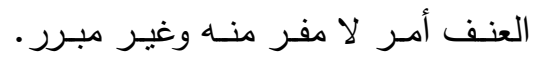

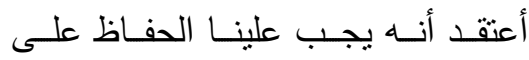

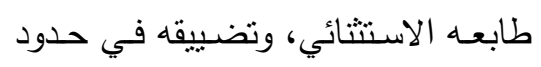

$$
\begin{aligned}
& \text { ما نستطيع" ('). (محاولات، ألبير كامو ) }
\end{aligned}
$$

(1) Albert Camus, Essais, éd de la Pléiade, 1965, p. 315. 
79. 
تظهر عبارات ألبير كامو نرسخ العنف سواء في المجتمع السلمي أو في حالات النزاع

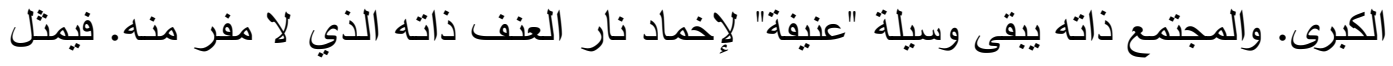

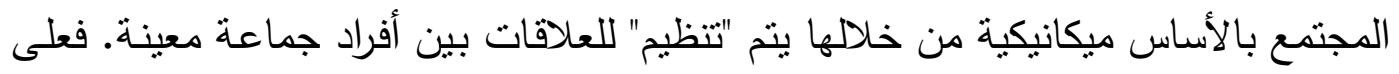

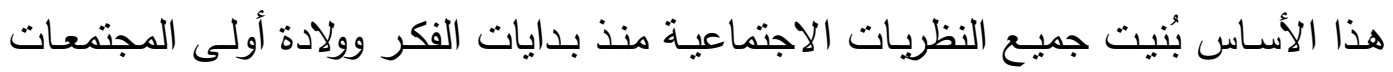

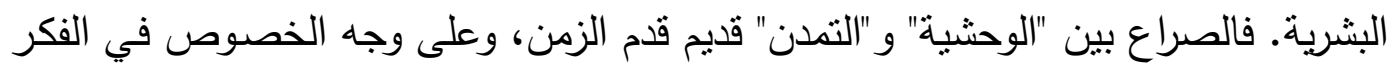

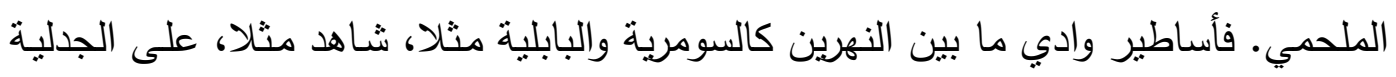

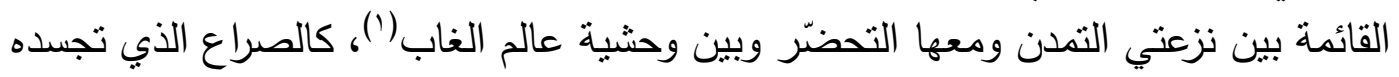

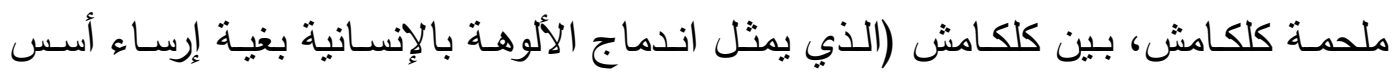

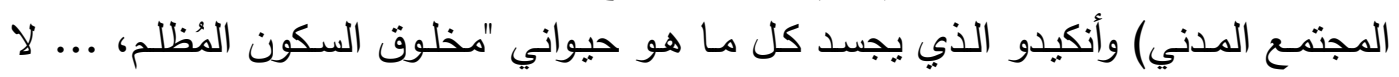

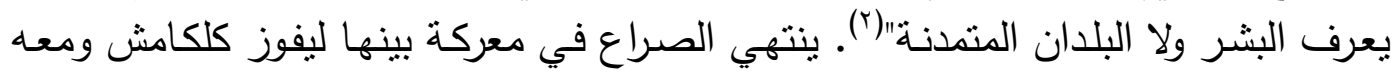

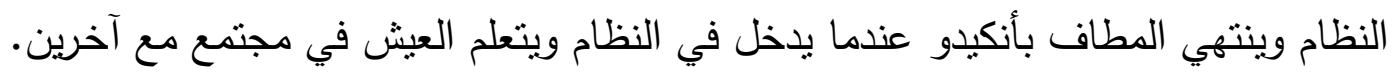

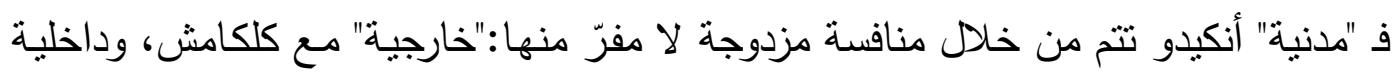

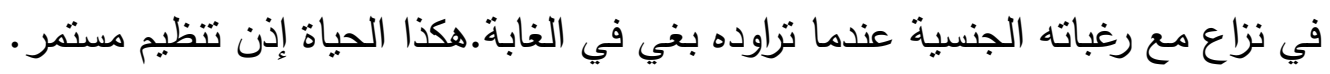

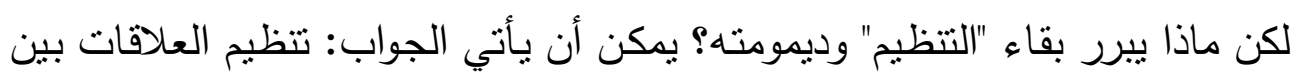

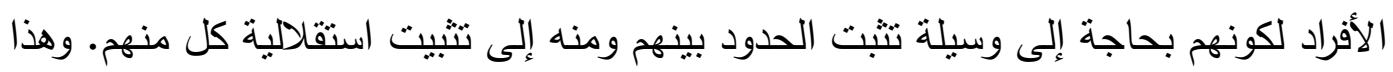

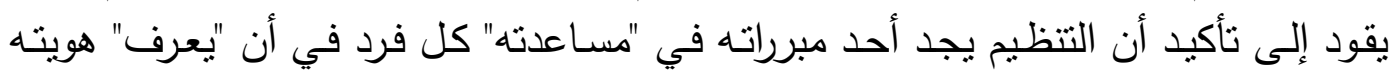

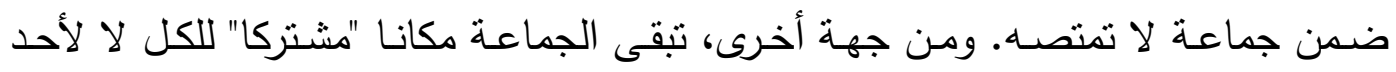

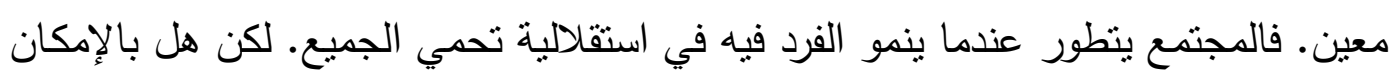

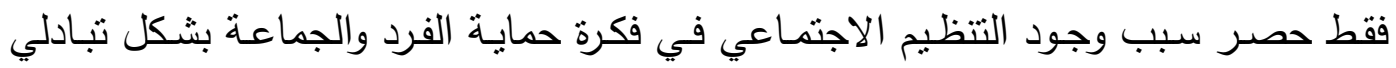

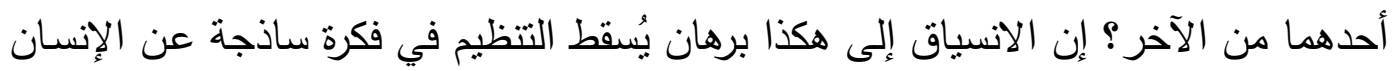

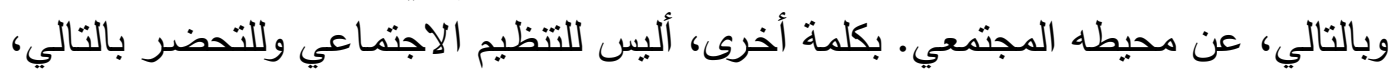

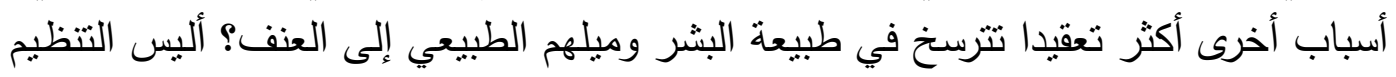

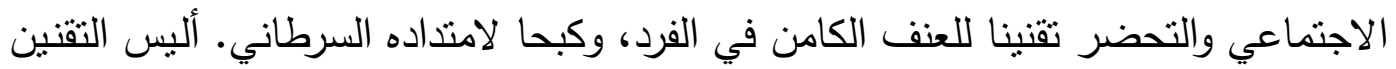

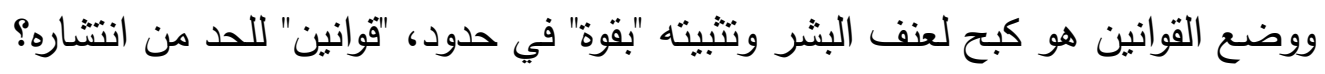

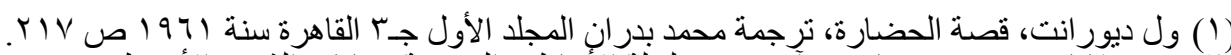

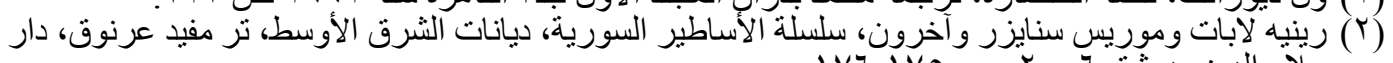

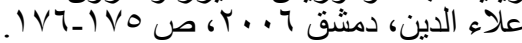




\section{ا. التمدن والعنف لاى أفلاطون وأرسطو:}

تظهر مفارقة التحضـر والعنف بشكل صـارخ لدى فلاسفة اليونـان. فقدمت الفلسفة

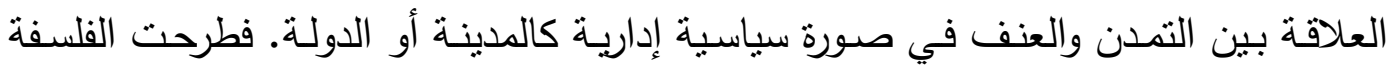

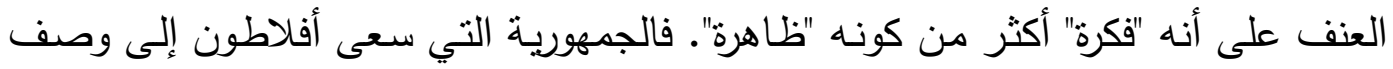

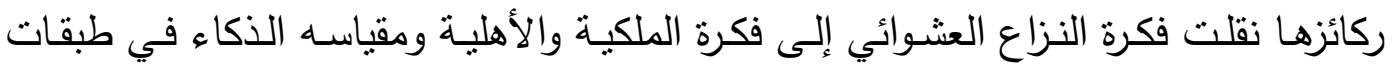

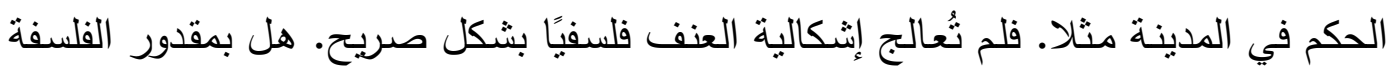
أن تتعامل مع العنف كموضوع بشكل جدي فيصبح موضوعا لدراستها؟ أـ أفلاطون، إثكالية العنف في كتاب "الجمهورية":

في المجال السياسي، تبدو "نظرية المثل" مختلفة جدا. عندما نترجم رغبة أفلاطون في

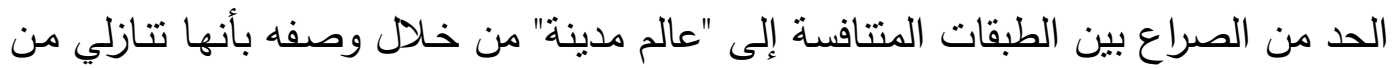

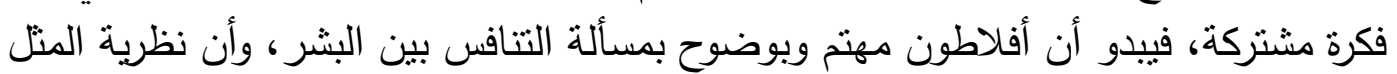

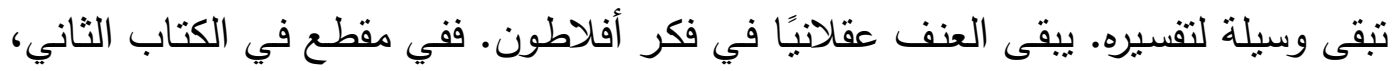

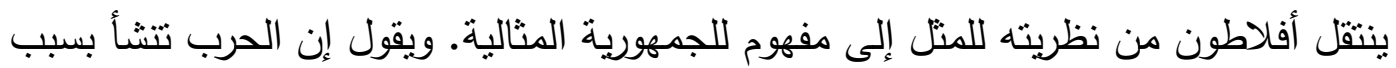

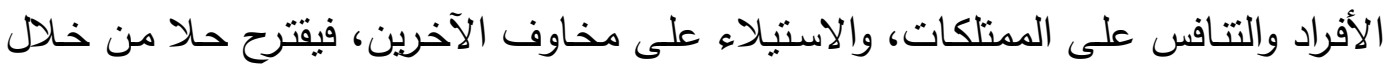
إنشاء النوع نفسه من الترتيب الهرمي الموجود في مجال المنل ليطبقه في السياسة. في حالة

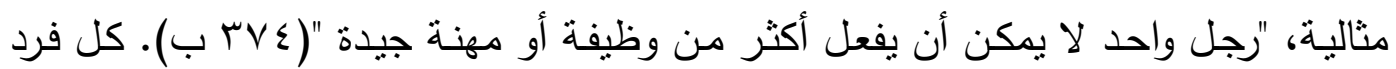
يمثل نوعا من الحرف، وهو الطابع الذي يملي عليه مواهبه، ونشاطه، لا بل سبب وجن وجوده. وطالما بقي الأفراد طائعين ولا يبتعدون عن ذلك، سوف يبقى الانسجام موجودًا في المدينة. فعندما نظرّ أفلاطون كل شيء بما في ذلك طبيعة الإنسان وعلاقاته مع الآخرين، فقد فنشل في حساب الطبيعة غير العقلانية للعنف، على الرغم من أنه حاول إعطاء علاج لذلك. فقد نسي أن العنف ينمو وفق نمط محاكاة (mimetism) حيث الأفراد يريدون امتلاك الأشياء

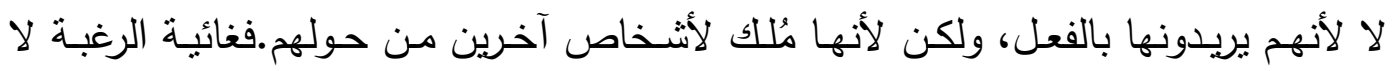

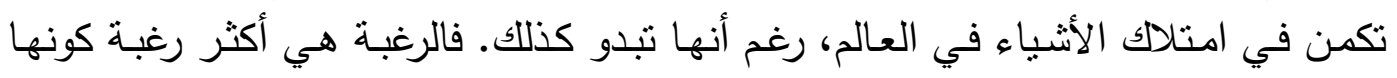

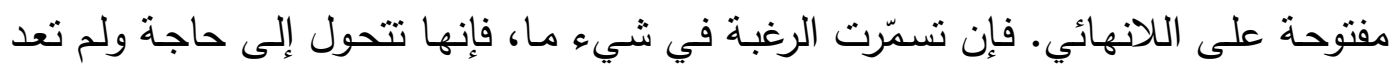
رغبة. إنها تعتمد على البعد الوجودي بين الأفراد والذي يبقى نبعًا. فالرغبة بطبيعتها تستتد

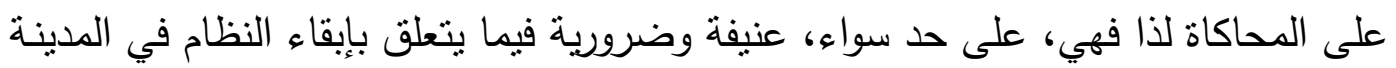
ومعـه التوافق المجتمعي ممكنا؛ فإن الصراعات التي لا مفر منها في مثل هذه المحاكات التي تولدها الرغبة، تؤدي إلى العنف الاجني التماعي. 
يعالج افلاطون كلا من هذه المشاكل الاجتماعية بضمنها العنف، وفق منظور مثالي.

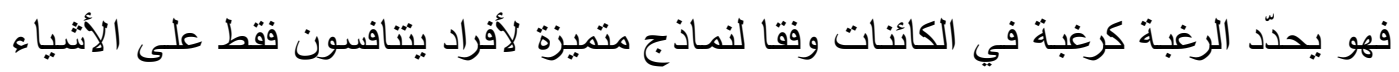

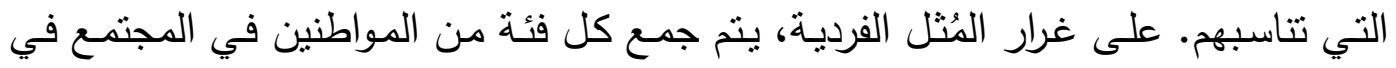

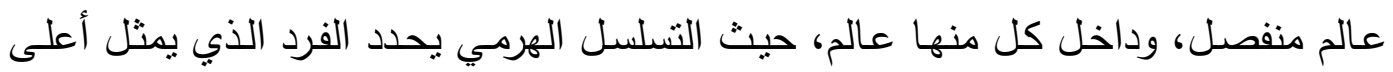

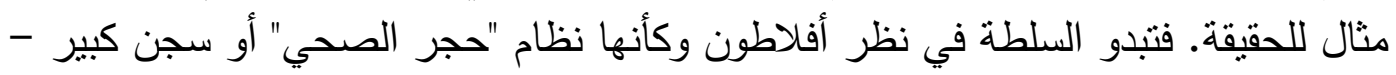

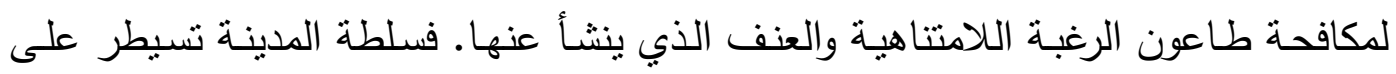

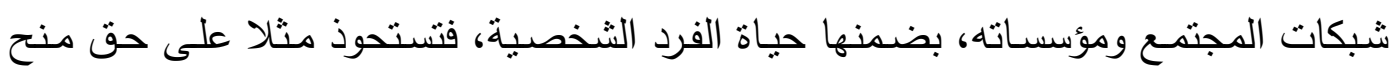

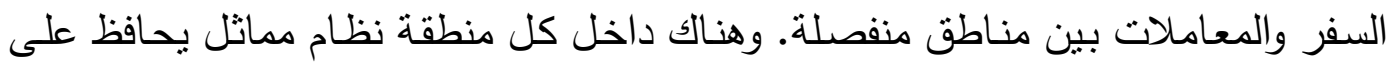

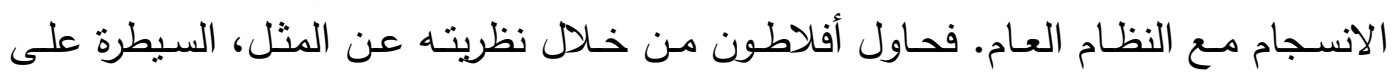

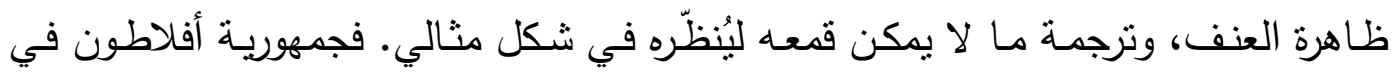

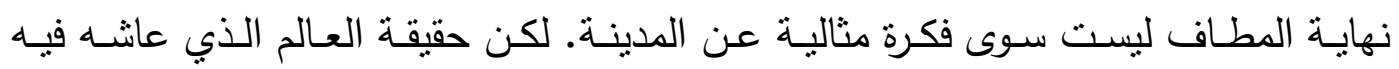

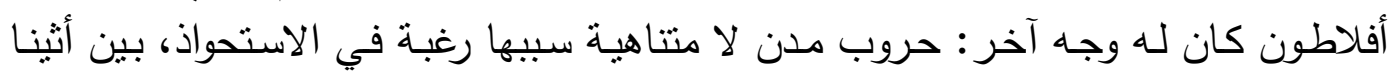
واسبارطة وغيرها من مدن اليونان القديمة.

ج- أرسطو: التمدن ومفارقةالإنسان حيوان اجتماعي، (كتاب السياسة):

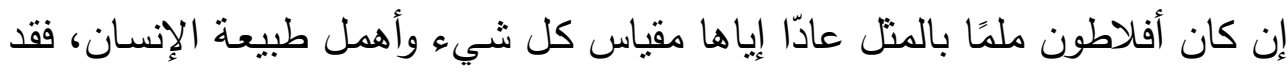

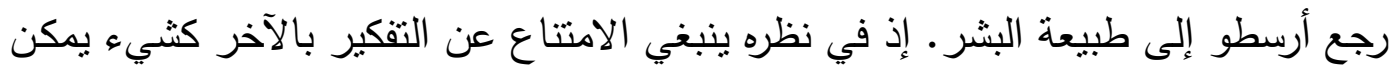

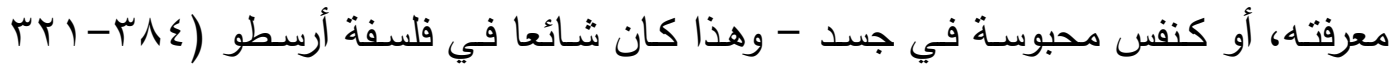

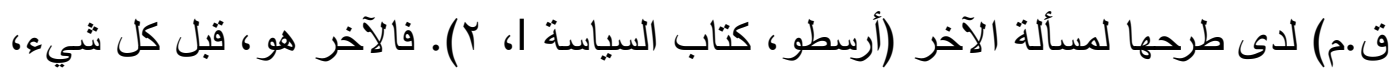

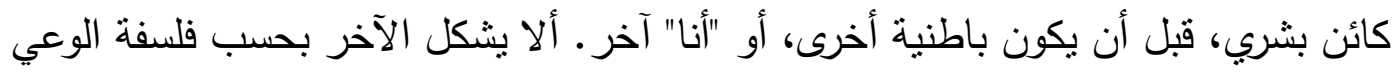

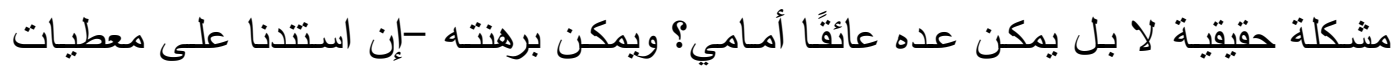

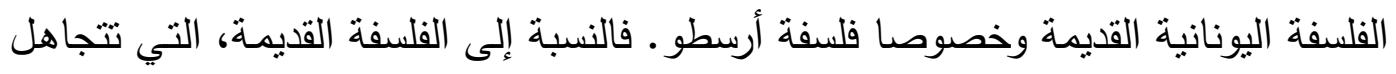

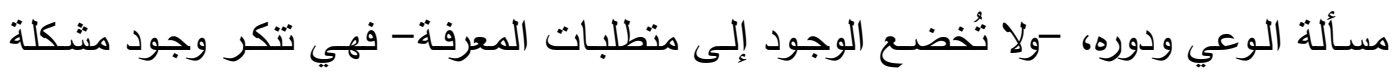

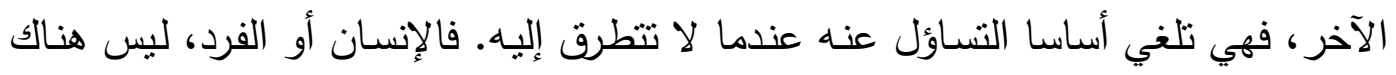

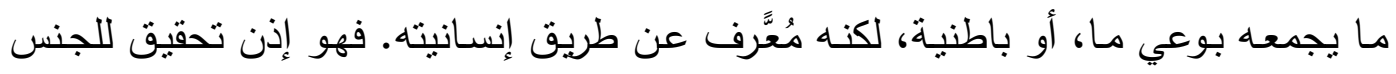

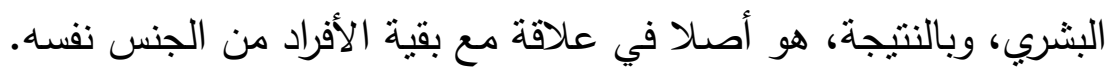

اــ الفرد: إما بهيمة أو إله:

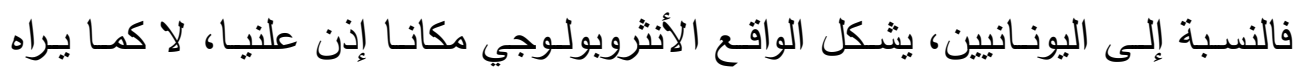

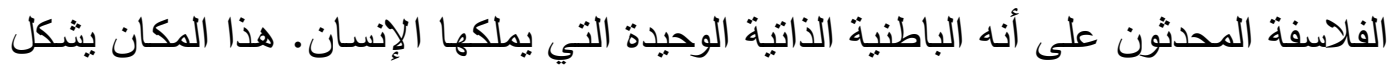


مـا يطلق عليه أرسطو بـ "ثـأن البشر". وهذا يعني بـأن النفس ليست مسؤولة عن تزويد

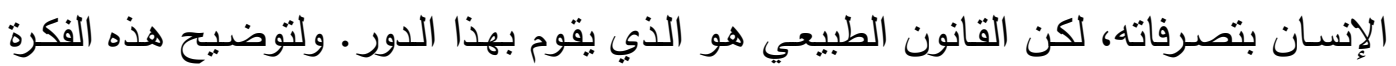

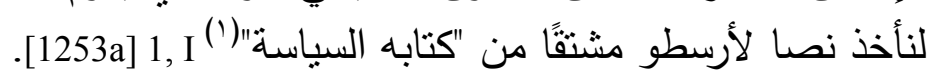

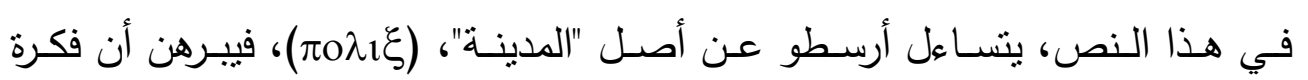

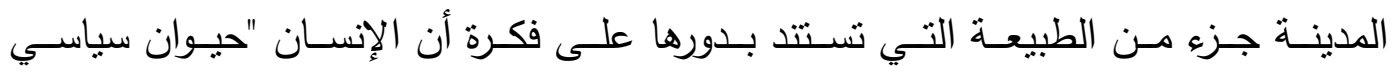
(اجنماعي)". (المدين)

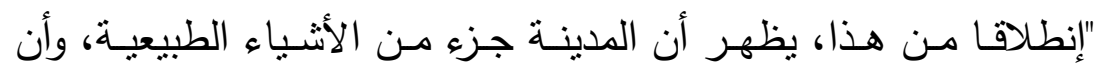

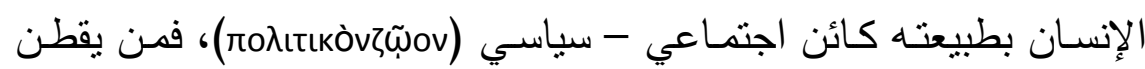

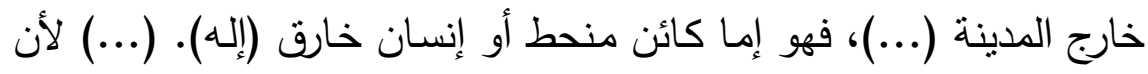

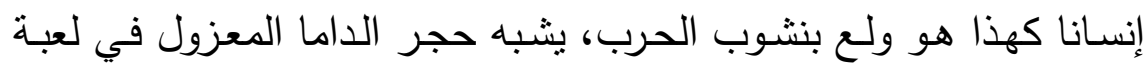

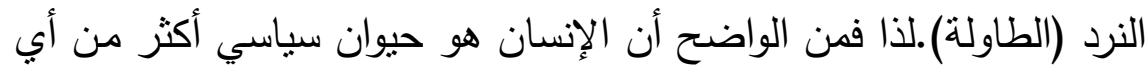

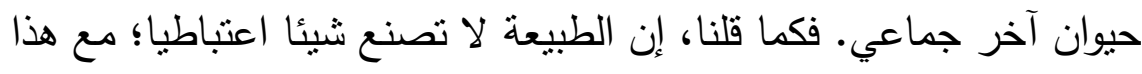

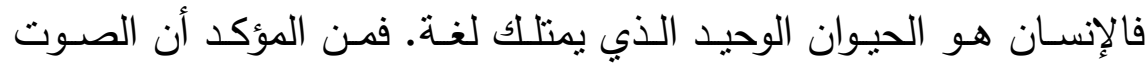

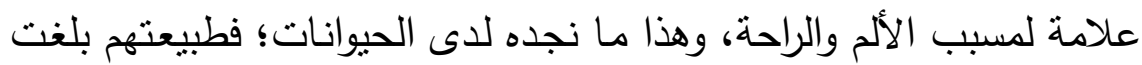

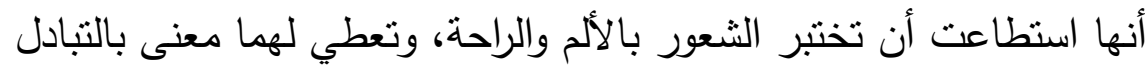

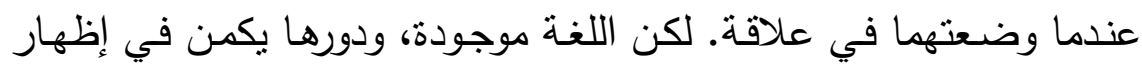

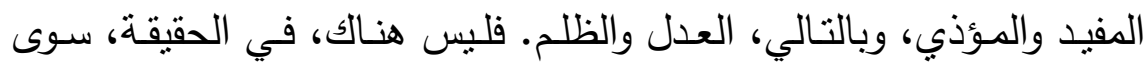

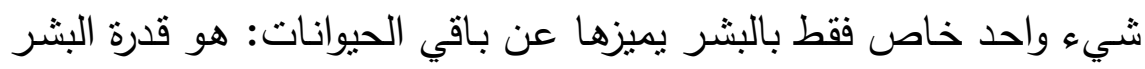

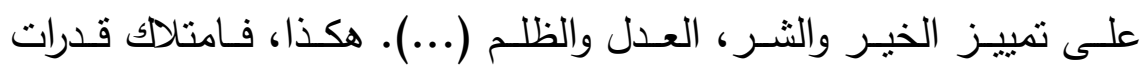
مشتركة كهذه، يخلق عائلة أو مدينة".

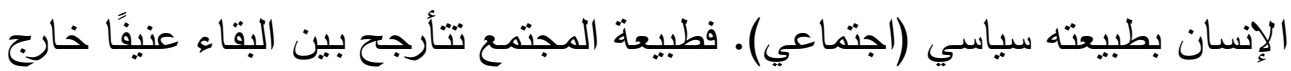

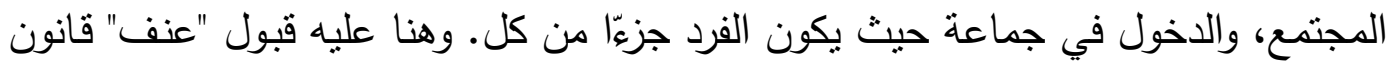

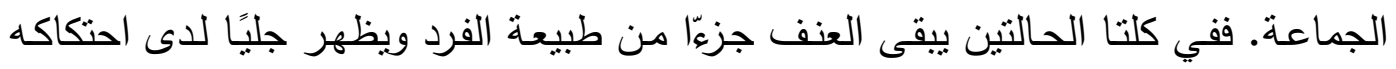
بالآخرين. ويضيف في النص نفسه:

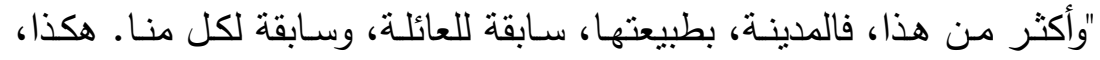

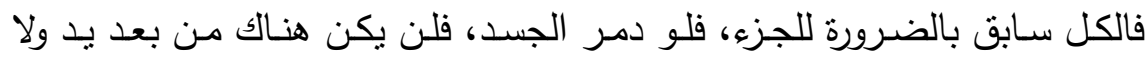

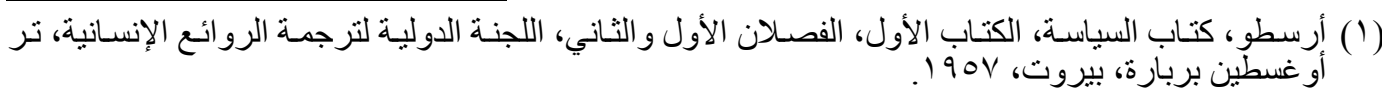




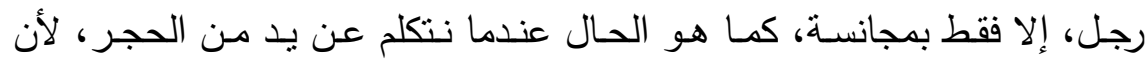

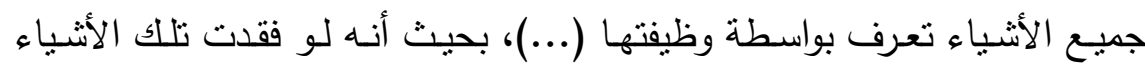

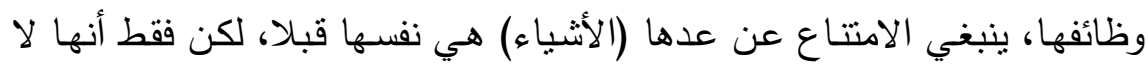

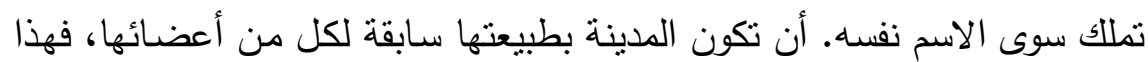

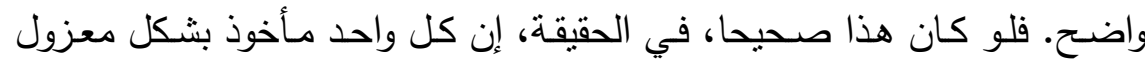

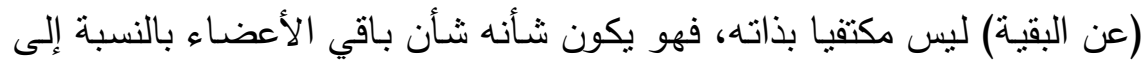

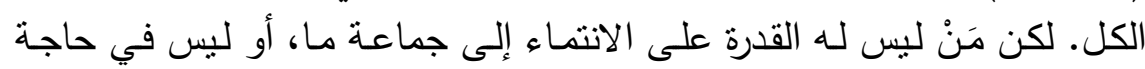

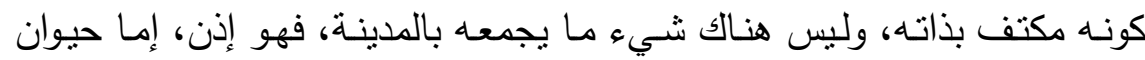

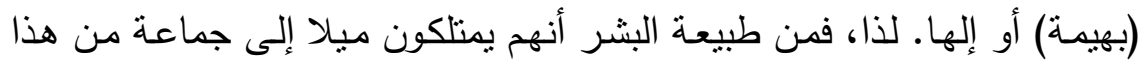

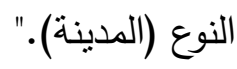

فعندما يكتب أرسطو "في طبيعة الإنسان ميل إلى العيش في المدن"؛ فهو يحاول

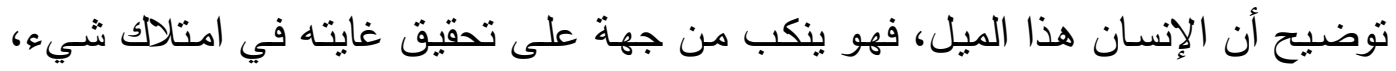

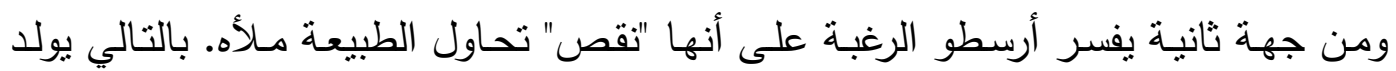

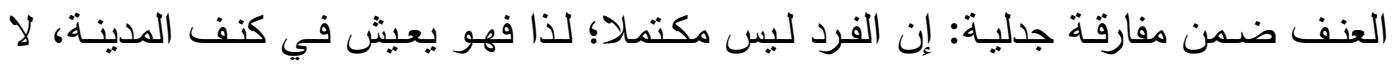
بسبب مصلحة، لكن ليحقق هناك سعادنه. هكذا فاكتمال الفرد مرهون بقدرته على الإنى الاحتكالك

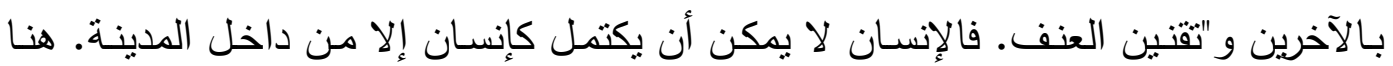

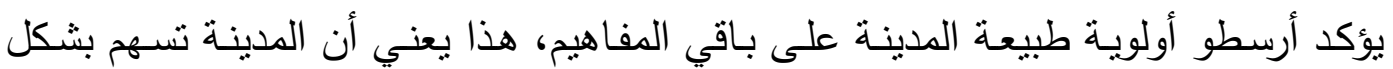

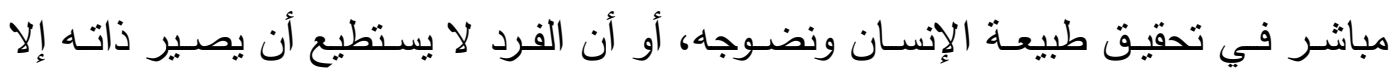

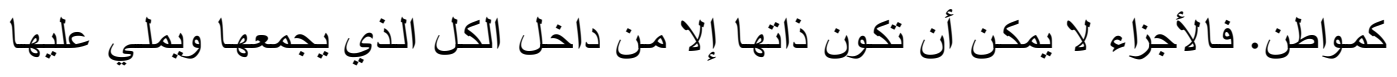

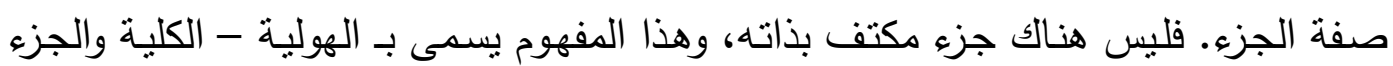

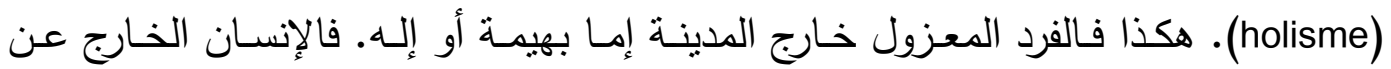

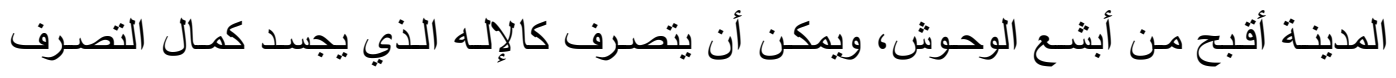
الأخلاقي من خلال انسجامه مع قوانين الطبيعة.

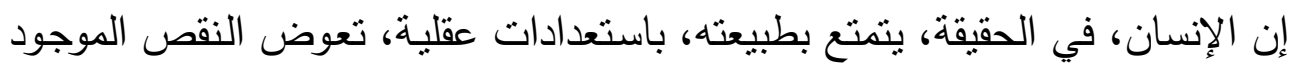

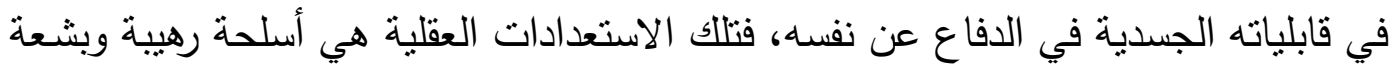

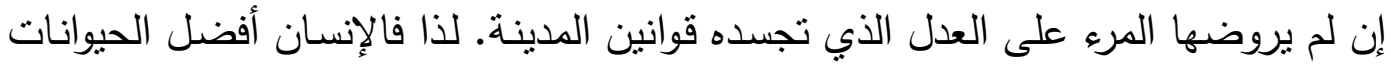

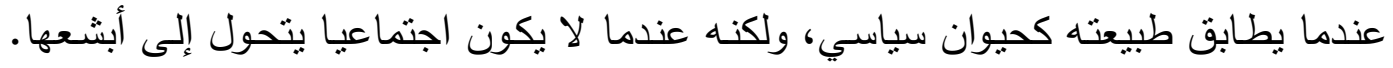
فالفرد الخارج عن المدينة هو من فقد إذن إحدى أهم صفاتها معنى العنى العدل. 
بالنتيجة، فالبشر في حاجة إلى بعضهم. فالإنسان لا يمكن أن يُعرَف إلا من خلال

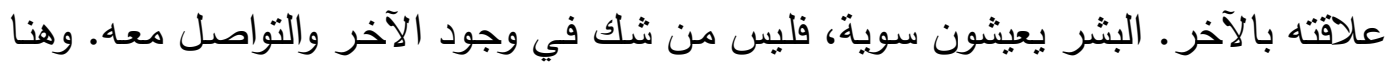

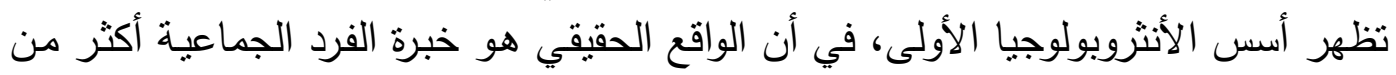

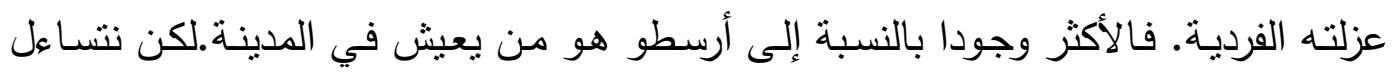

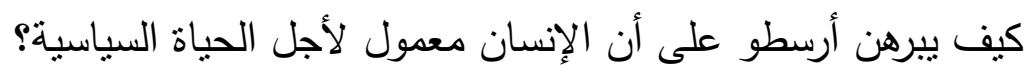
في النص أعلاه، يقدم أرسطو ثلاثة براهين: / / لا تصنع الطبيعة شيئا بشكل اعتباطي.

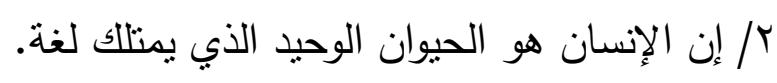

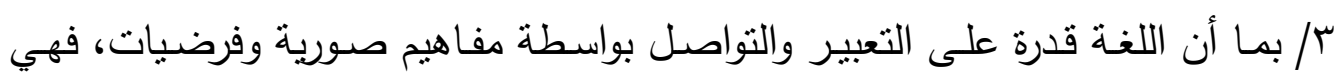
تصف موضوعا معينا: القيم الاجتماعية. 1ـ القدرة اللغوية، وسيلة تقنين العنف:

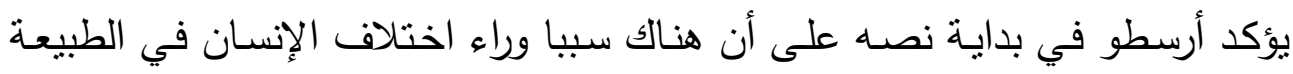

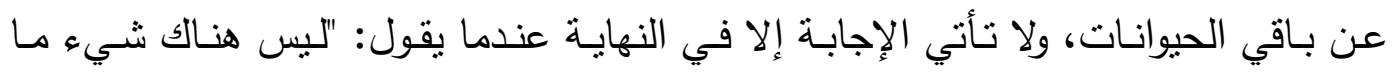

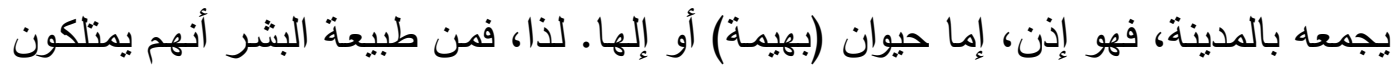

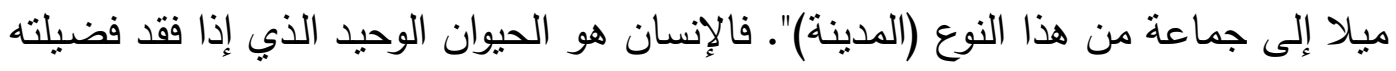

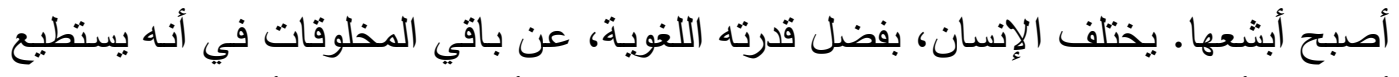

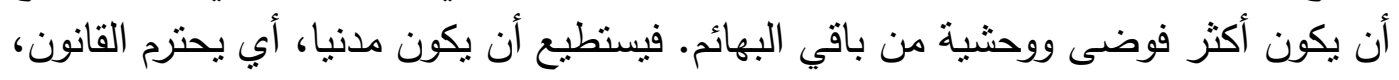

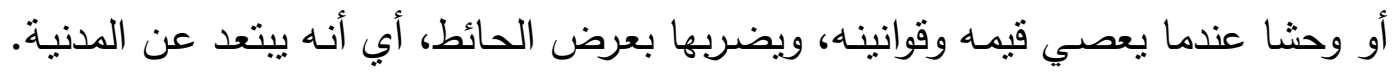

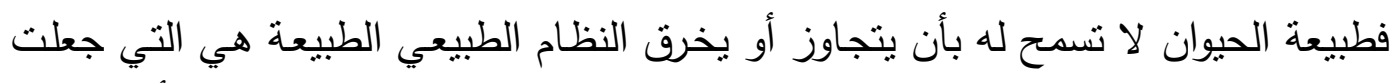

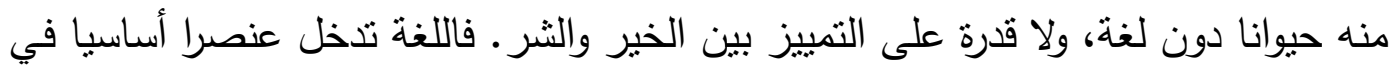

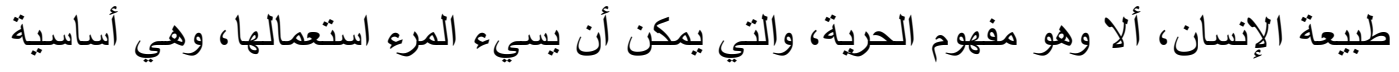
كي يستطيع الإنسان أن يحقق ذاته. فالتمييز الأخلاقي مبني على الألى الحرية.

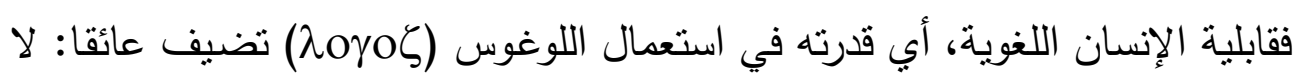

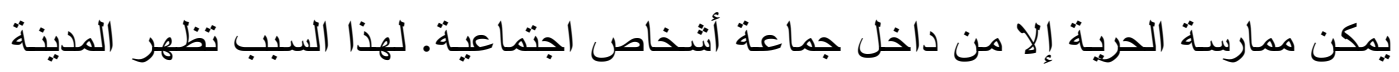

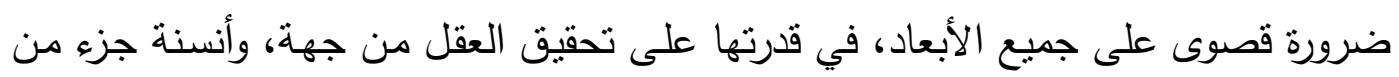

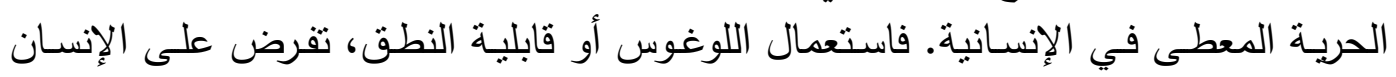

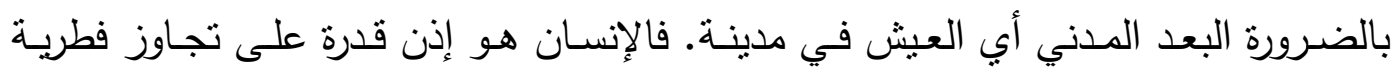


الرغبة وآنيتها، وتفهم للألم، أو حتى إظهار المفيد والمؤذب. كل هذا يتضمن في الوقت عينه

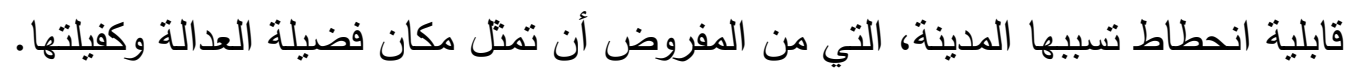
r- جين" ألبشرة" الطبعة والمجتمع: جان جالك روسو: "مقولة عن أصل اللامساواة

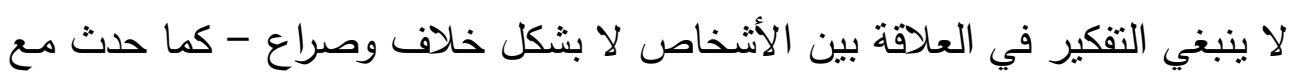

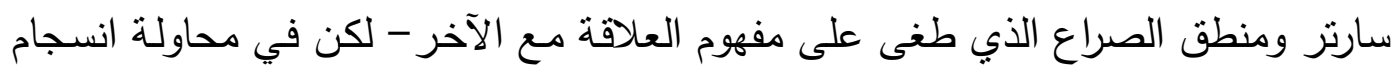

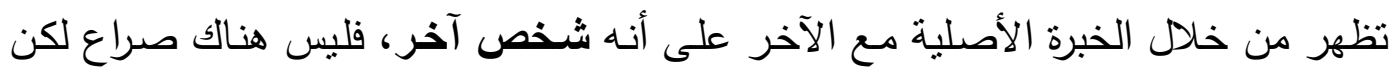

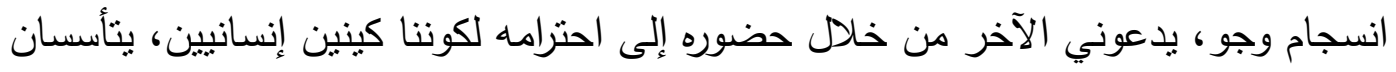

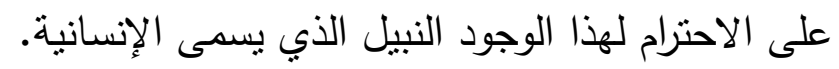

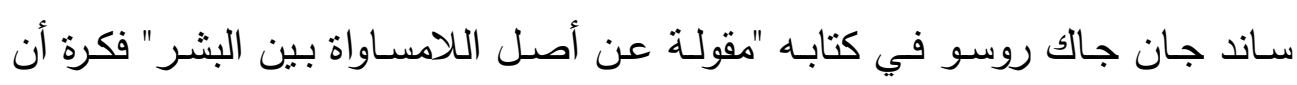

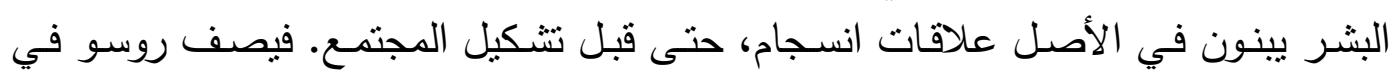

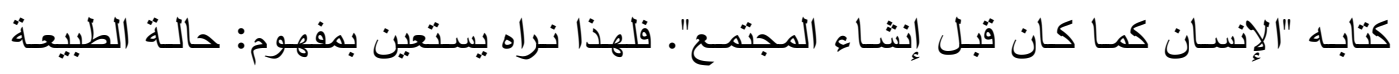

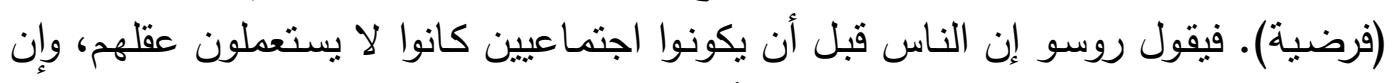

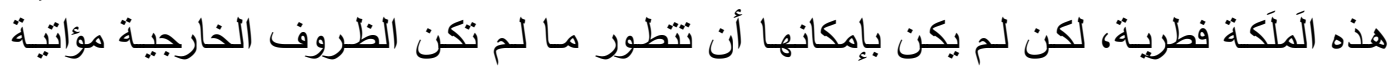

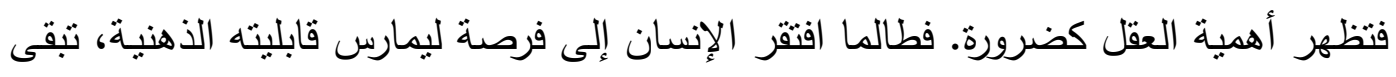

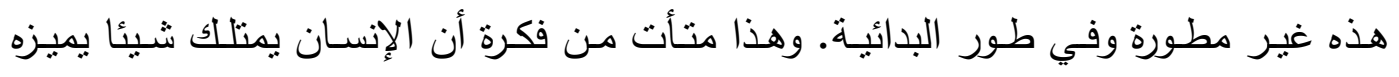

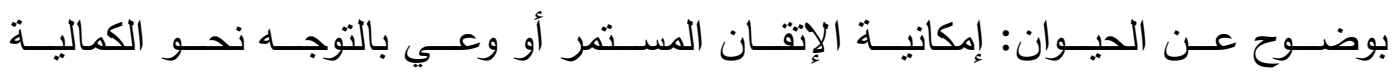
(perfectibilité)

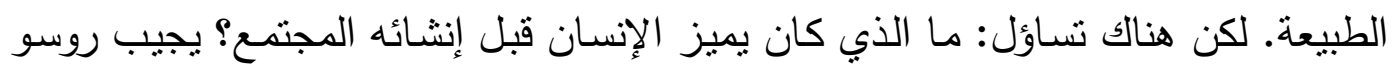

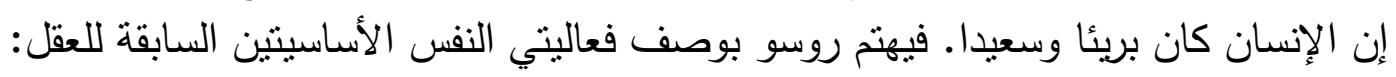

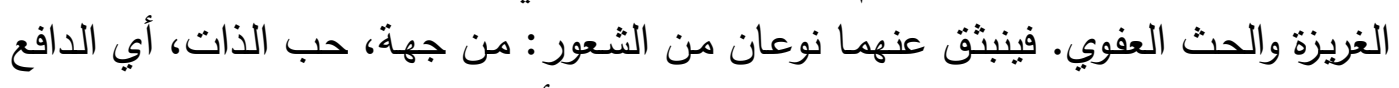

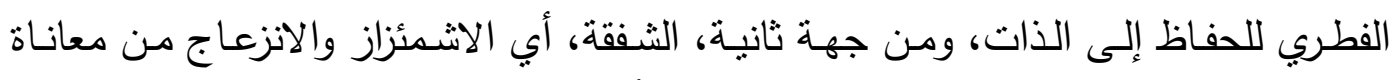
الآخر ، شبيهي، الرغبة في مساعدته للتخلص من ألمهن.

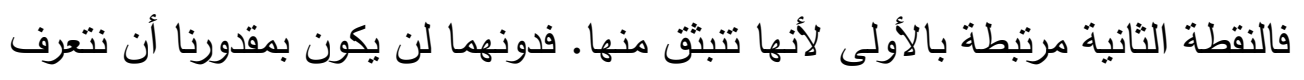

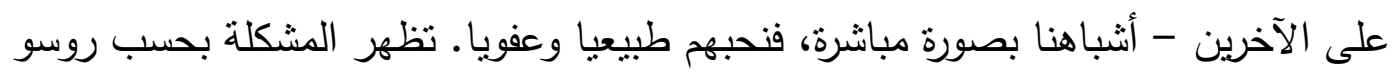

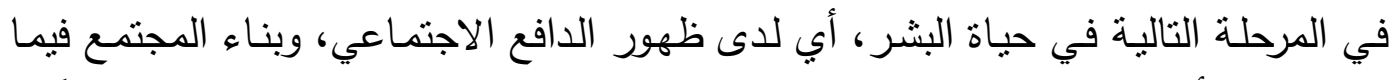

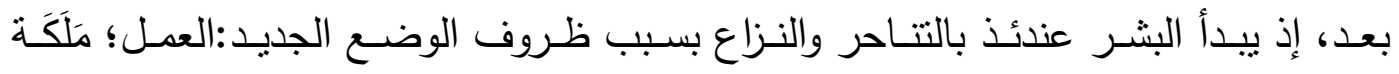

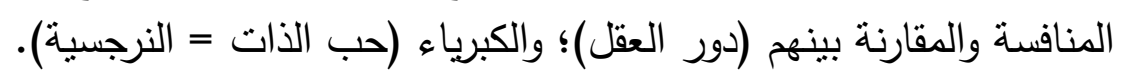


كأن روسو يجيب عن ما طرحه سارتر لاحقا، الذي أجاب معاصره توماس هوبز

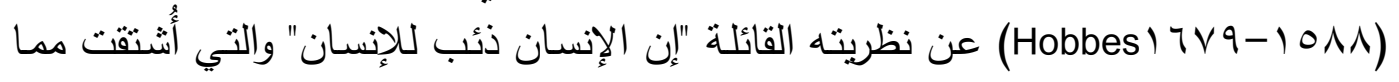

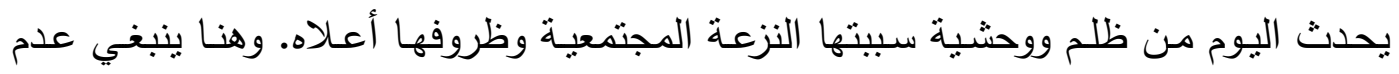

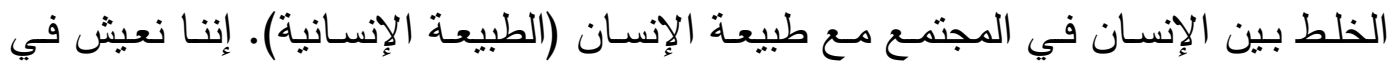

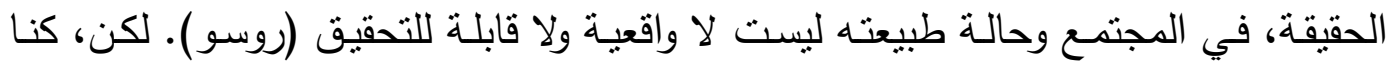

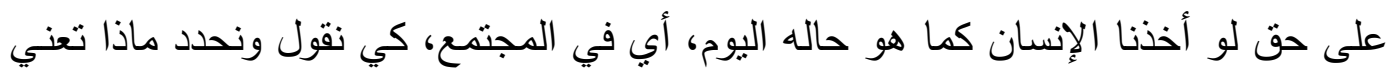

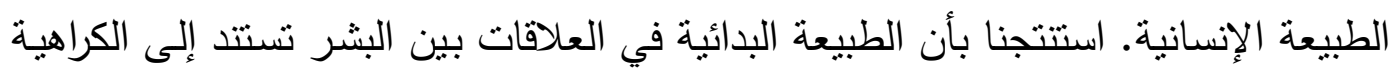

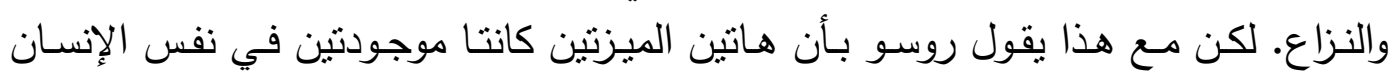

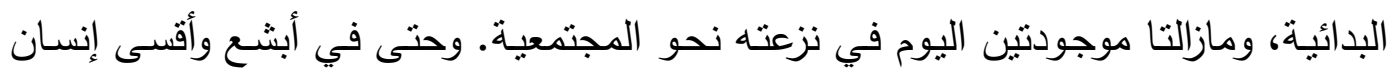

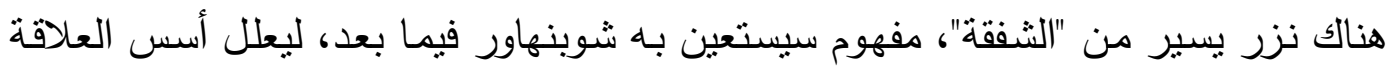

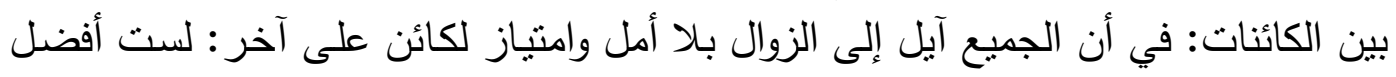

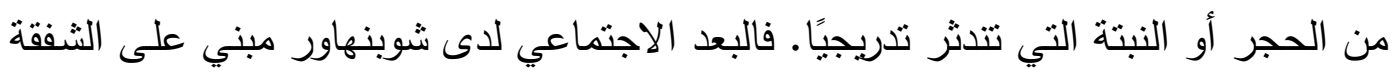
المتبادلة ضمن مصير مشترك.

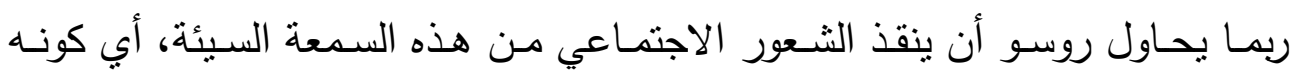

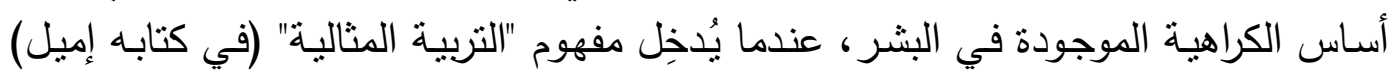

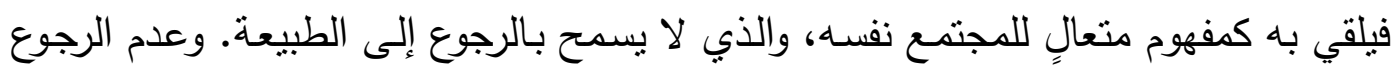

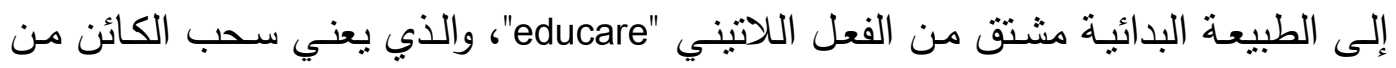

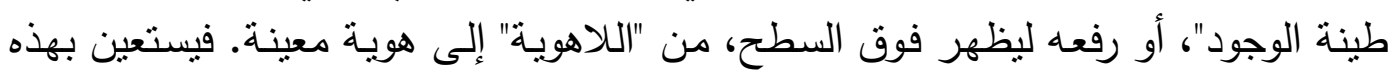

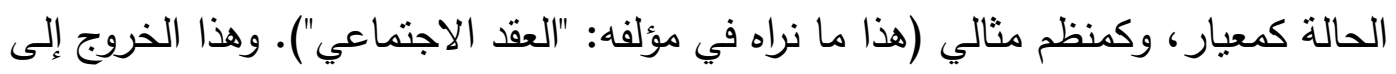

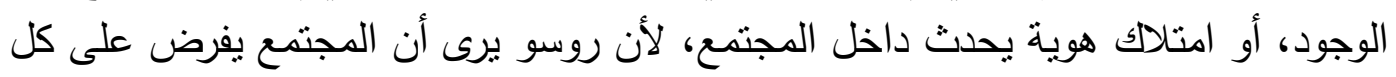

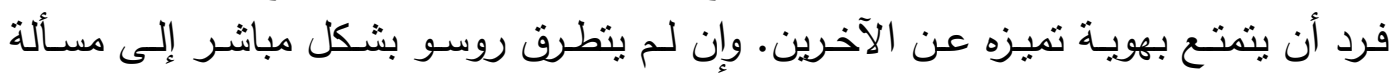

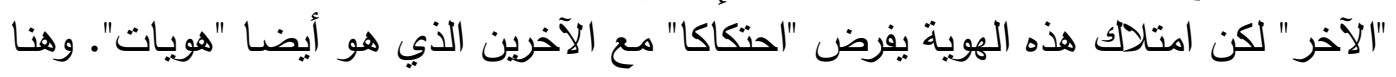

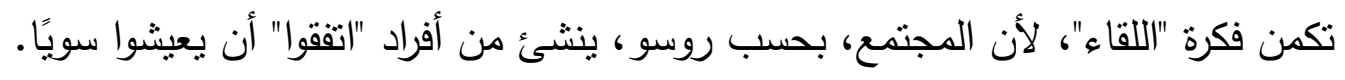

\section{r- مفارقة الطبيعة و الثقافة:}

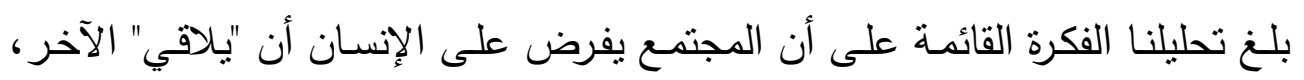

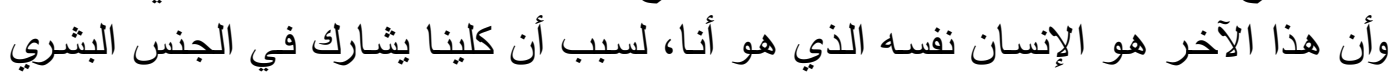

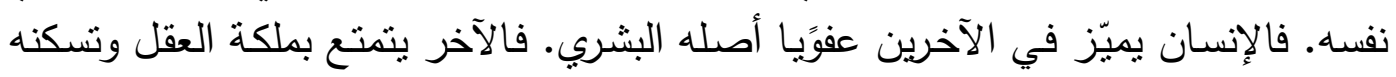

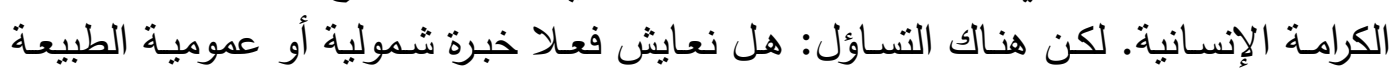


البشرية؟ هل يوجد الإنساني (human) حقا خارج جماعتنا وشعبنا؟ هل هناك أنموذج للبشرية يكون فوق كل الجزئيات والثنعوب على تتوع طبائعها وعاداتها؟

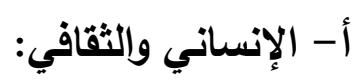

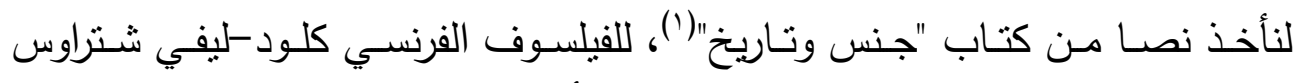

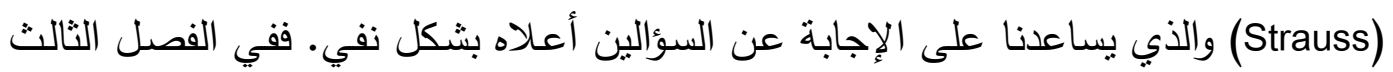

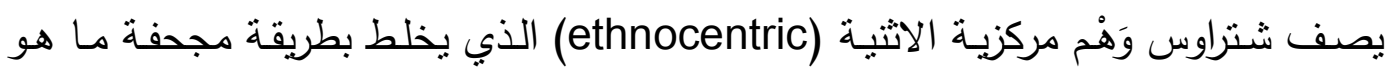
ثقافي وما هو طبيعي، فيقول:

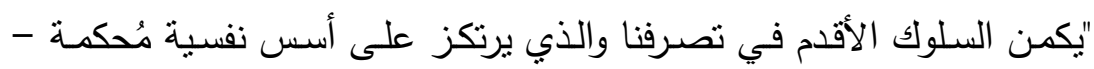

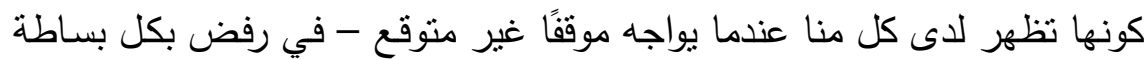

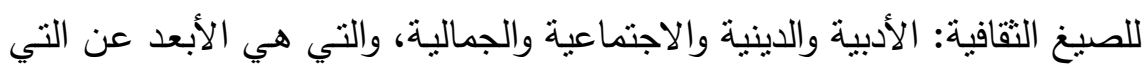

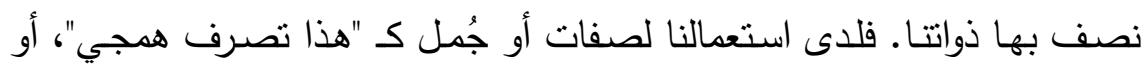

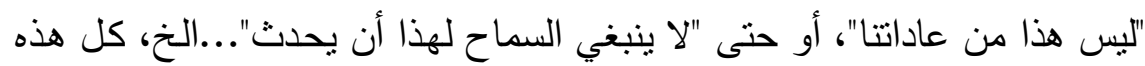

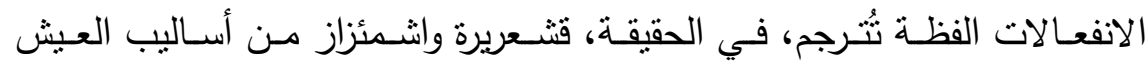

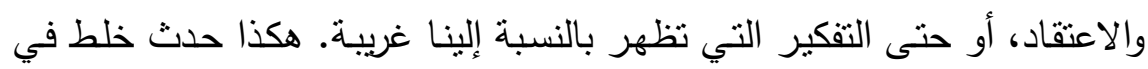

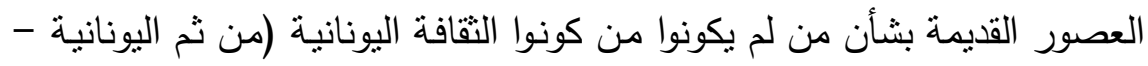

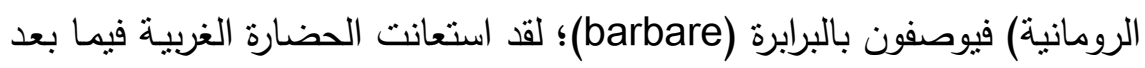

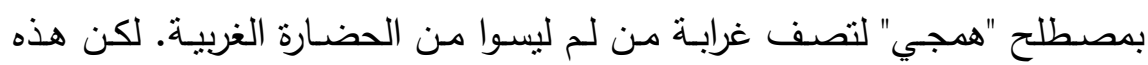

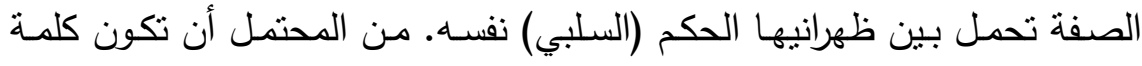

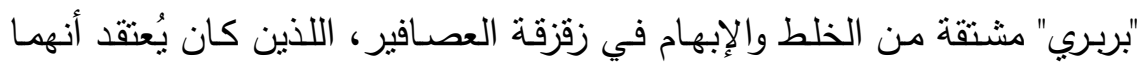

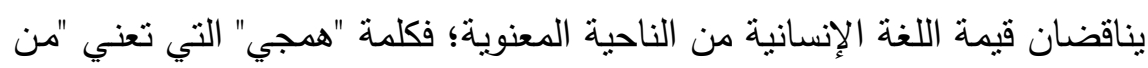
الغاب"، تتوه إلى أسلوب عيش الحيوانية من الناهي الذي يتعارض مع ثقافة الإنسان".

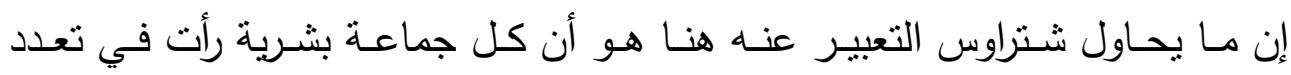

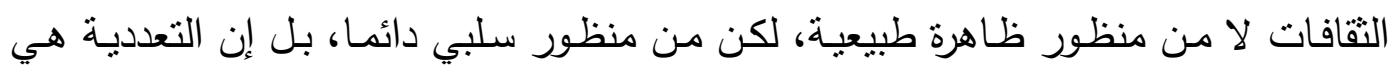

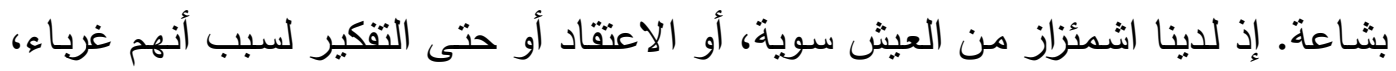

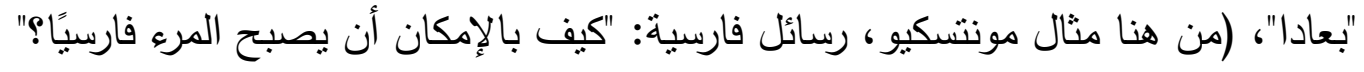

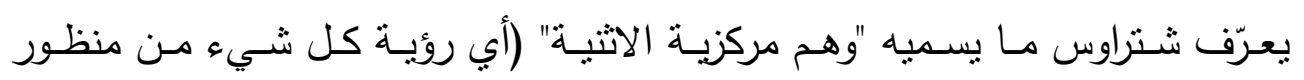

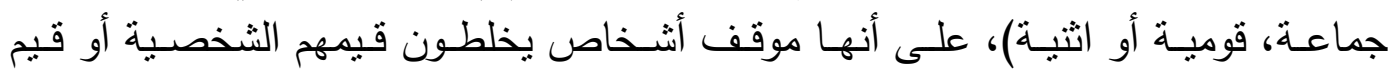

(1) ClaudeLévi-Strauss, Race et Histoire, collection Médiations, Éd. Denoël-Gonthier, 1968, pp. 19-22. 


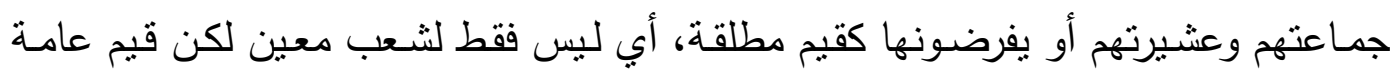
(universel)

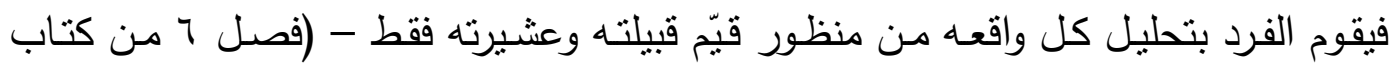

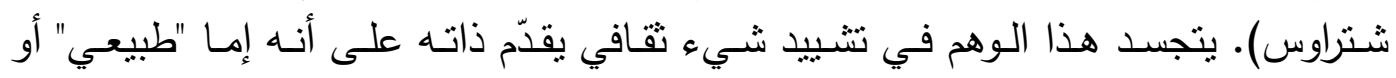

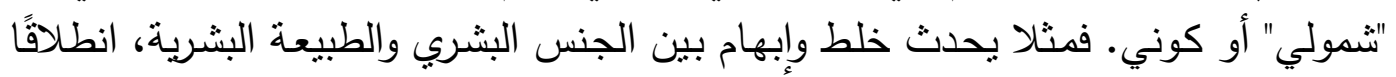

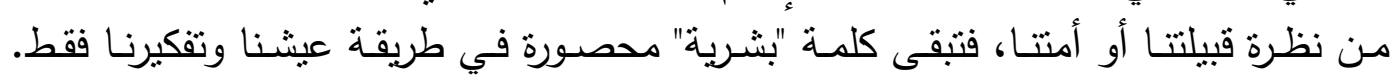
ويتابع شترواس في المكان نفسه:

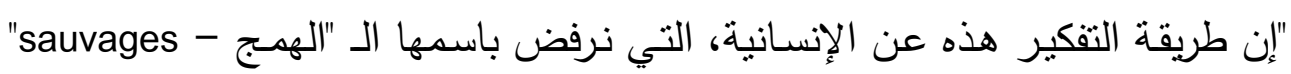

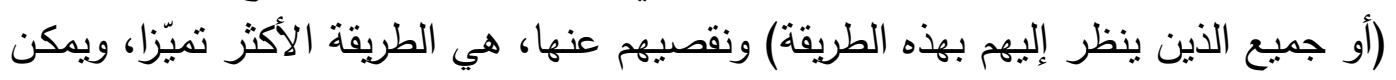

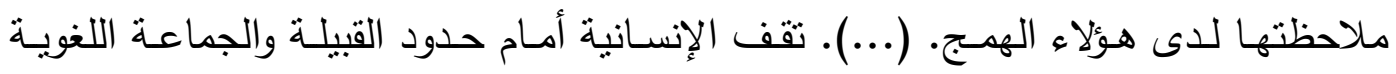

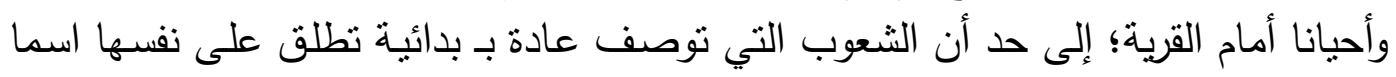

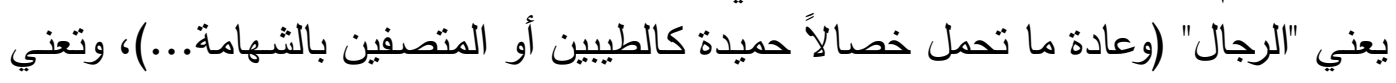

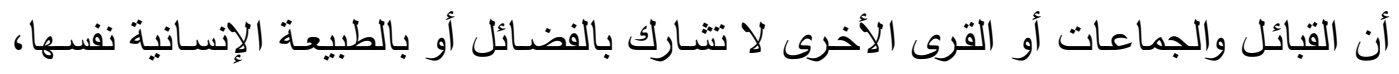

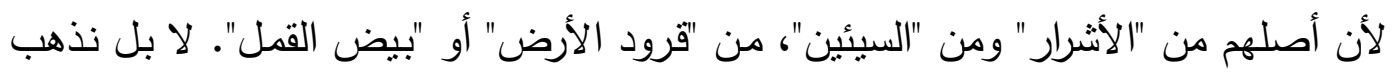

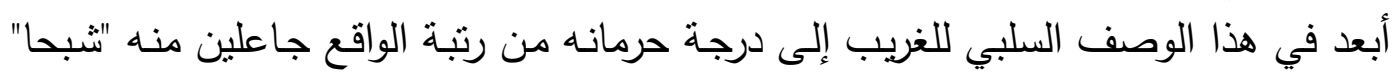

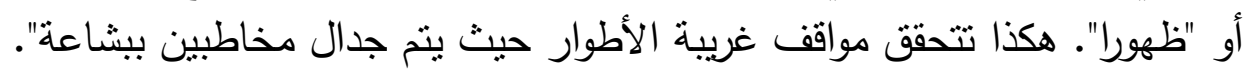

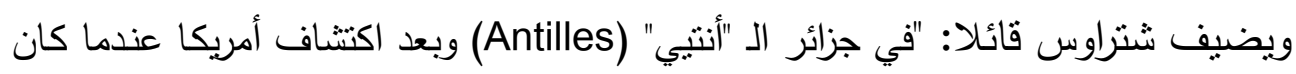

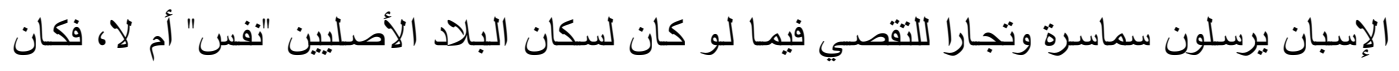

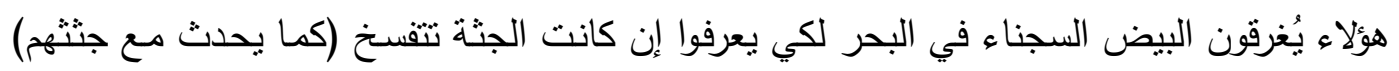

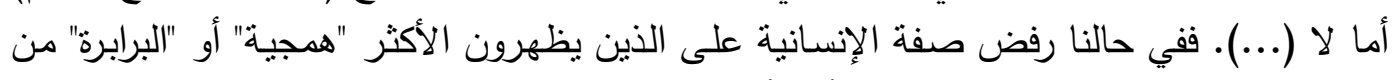

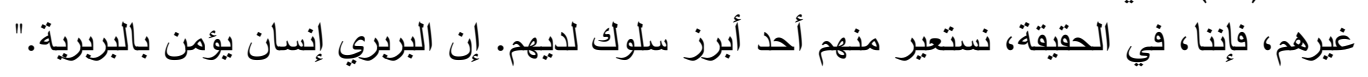

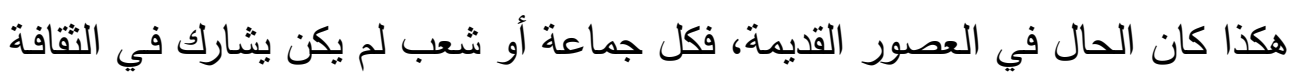

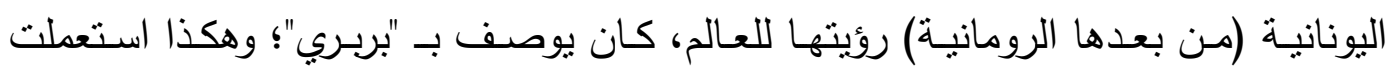

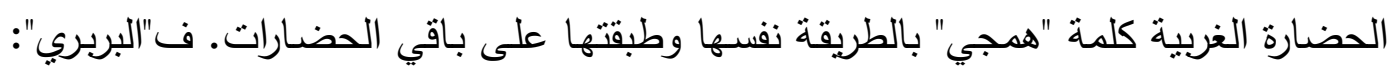

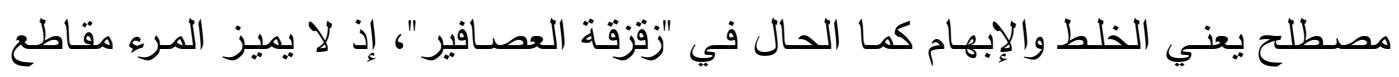

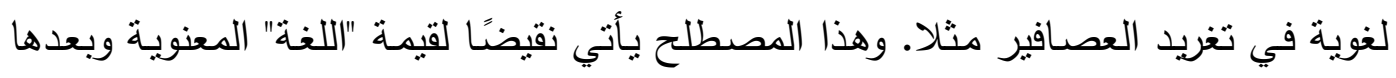

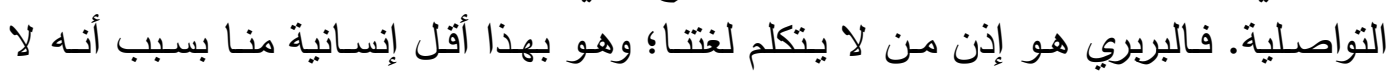

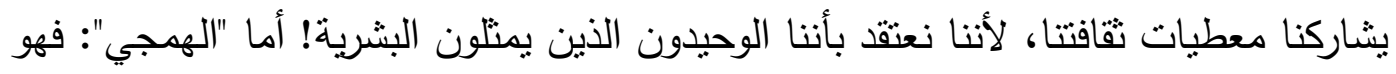




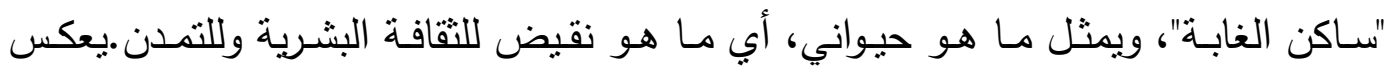

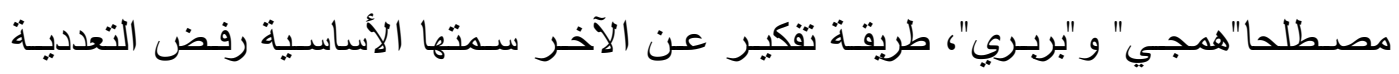

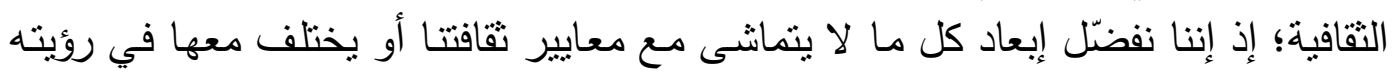

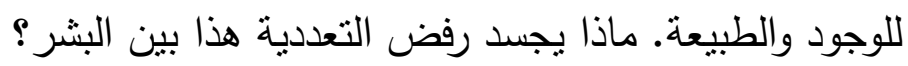

\section{ب- إثكالية الغيرية وجهل الآخر:}

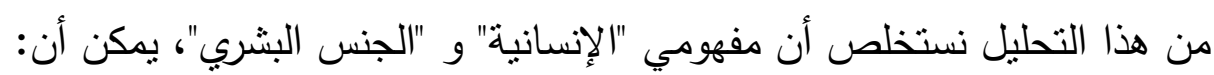

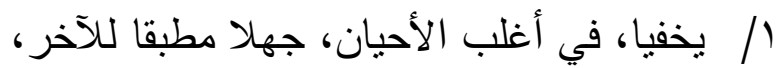

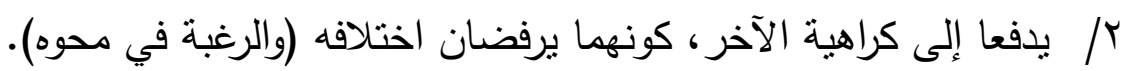

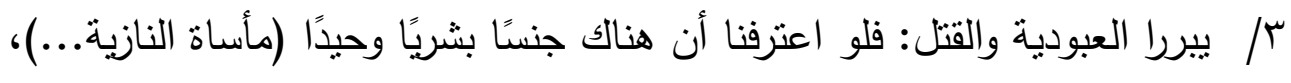

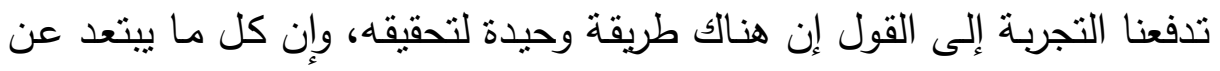
هذه الطريقة لهو ابتعاد عن الإنسانية.

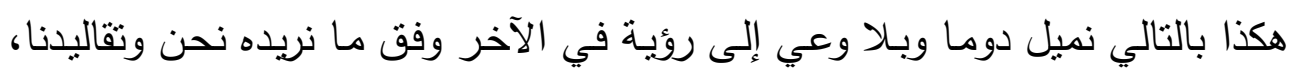

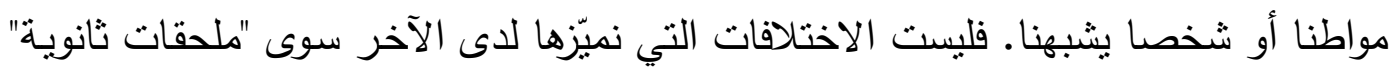

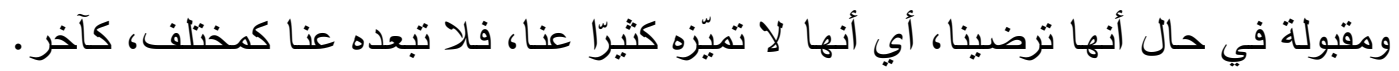

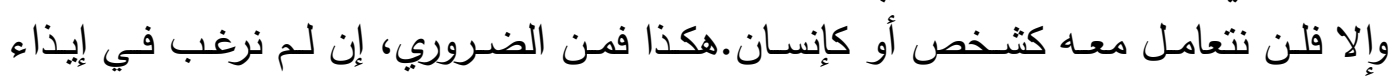

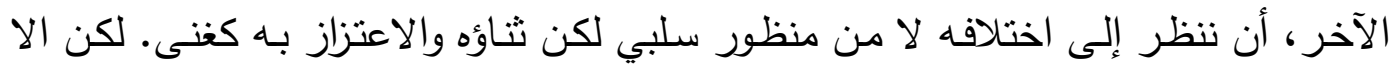

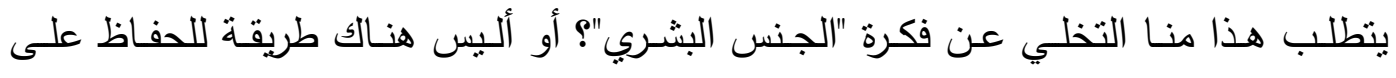

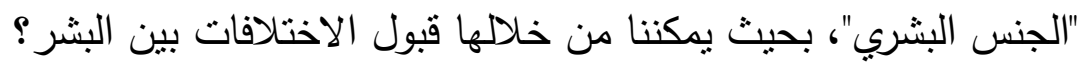
أ- احترام الاختلافات:

أ. قيمـة الاختلاف، وقبول الآخر كمـا هو ،مـع اختلافهـ (كلود ليفي شتراوس - جنس

وتناريخ)

ا ـيقّر شترواس وبوضوح بأن فكرة التقدم "ما بين -جماعيـة" تشترط مسبقًا الإقرار

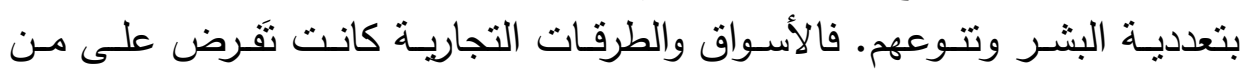

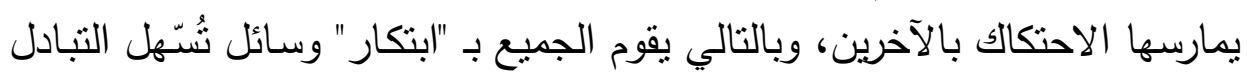

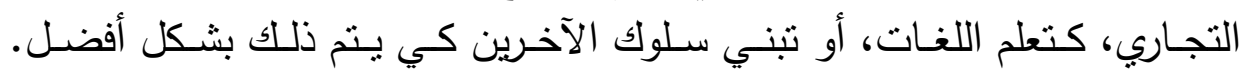

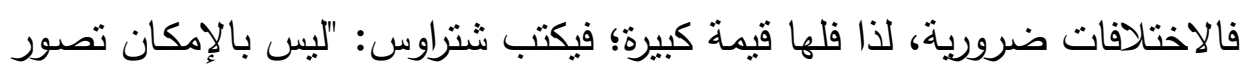

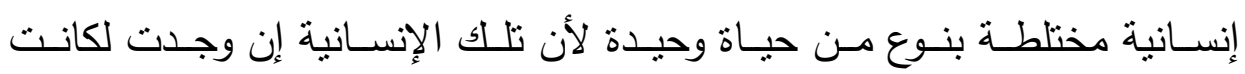


مُتكلسـة"(1)، لأن كل تقدم ثقافي هو خاصية ائتلاف بين الثقافات؛ ائتلاف مثرر

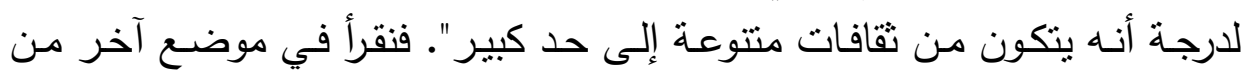

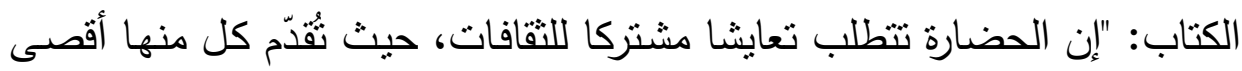

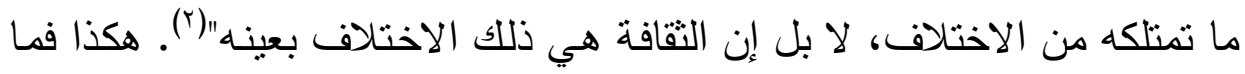

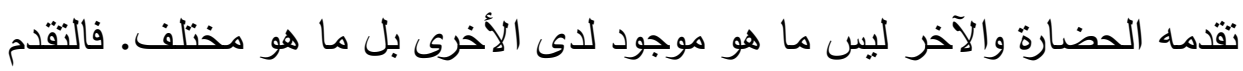
يولا ضمن "المختلف" الذي تقدمه كل حضارة من جهتها. هكذا، هنالك علاقة وثثيقة هوحئ بين "الاختلاف" و "التقدم.

r. لا يمنع الاختلاف - وإن لم نستطع فهمه كليا- من أن نتواصل مـع هو مختلف

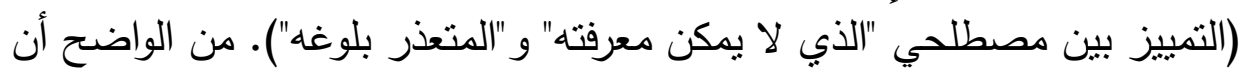

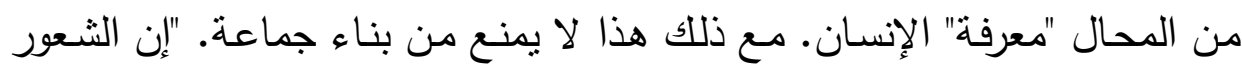

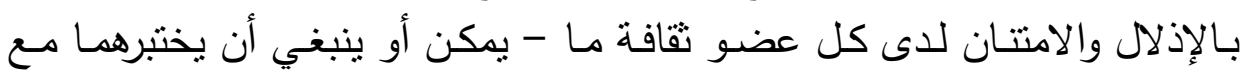

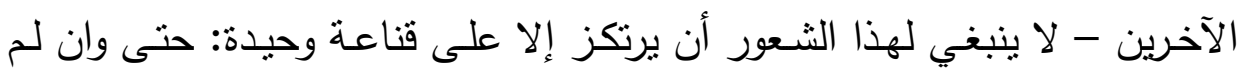

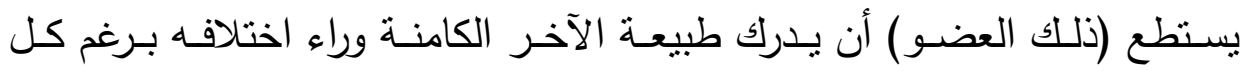
جهوده، أن يقتع أنه لا يستطيع إلا بشكل غير كامل أن يتوغل إلى داخل داخل وجود

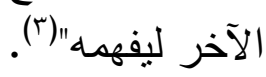

أدرك شترواس أن، من الناحية التاريخية، الاختلاف بين البشر لم يُفسّر ربما على أنه الهـ

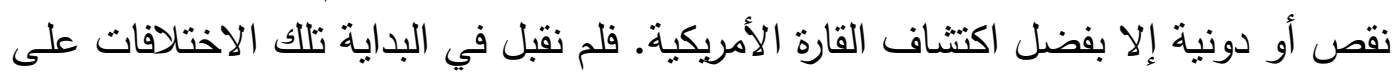

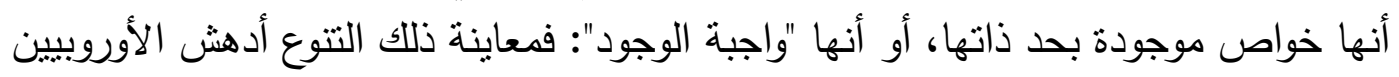
فبدأوا بطرحون أسئلة كهذه: هل للهنود نفس؟ هل هم بشر أم أم حيوانات؟ هكذا شرع الأوروبيون تدريجيا في النظر إلى الاختلافات بين البشر على أنها إيجابية.

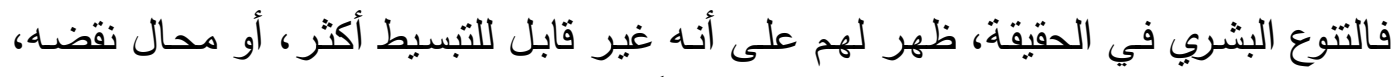
لأننا نكتشف تتوعًا بين البشر أكثر مما نجد نقاطًا مشتركة تجمعهم. فانكب المهتمون بدراسة فاسة

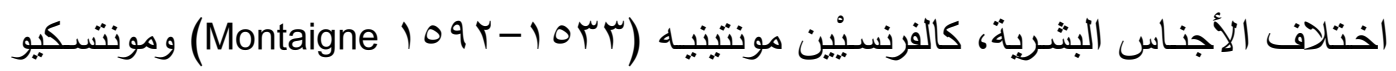

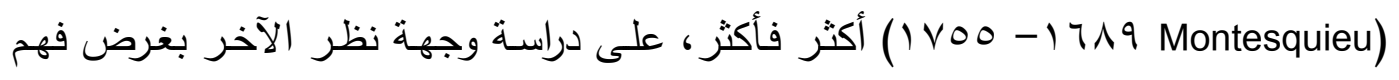

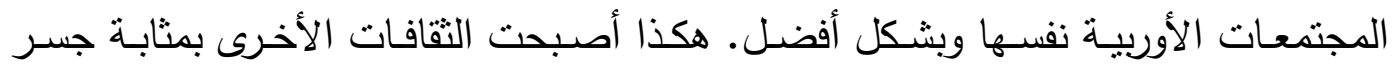

(1) ClaudeLévi-Strauss, Race et Histoire, collection Médiations, Éd. Denoël-Gonthier, 1968, p.83. 


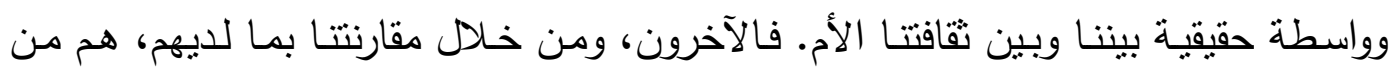
يدفعنا إلى أن نتعمق بشكل أفضل في ما لدينا، أي للتعرف على هويتتا. وهذا التعرف على الهوية يثير صراعا داخليًا ضمن أفراد كل جماعة أو مجتمع يظهر

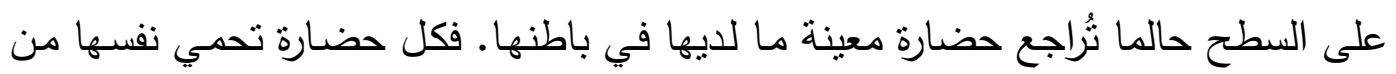
الخارج ضمن تحالف عنف أفرادها لتوجهه ضد الخطر الخارجي، لكن حالمـا يزول خطر فئه

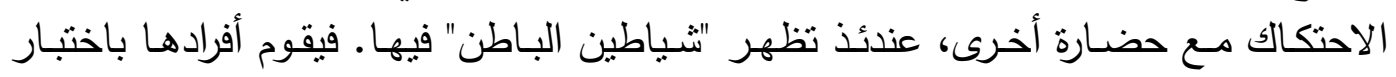
عنفه بشكل فردي وعشوائي. للعنف هدف مرغوب فيه، وهو فرض الهيمنة على الآخرين

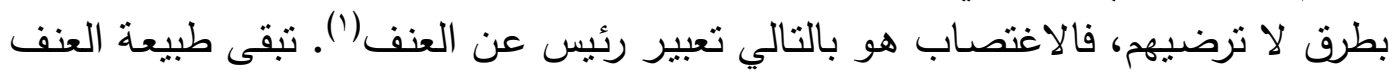

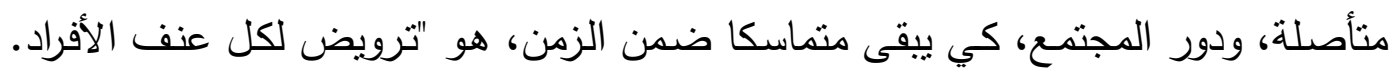
ويتم تحقيق هذا الترويض ضمن "سلطة المجتمع وممارستها ضمن عنف منظم ضد عنف هن فئف الفرد.

\section{r- التنظيم الاجتماعي والعنف:}

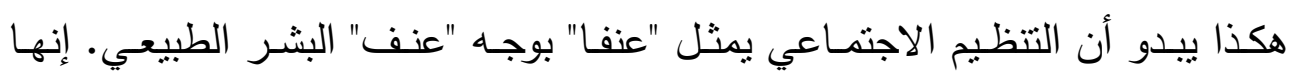

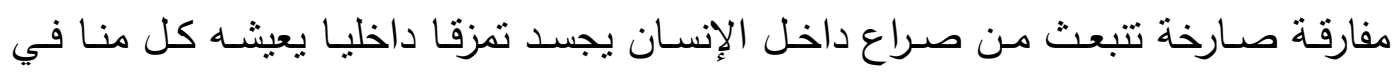
مسيرته الوجودية. فمن قلب هذا التمزق، تولد المفارقة الجدلية بين رغبة الإنسان في البقاءفي لإني

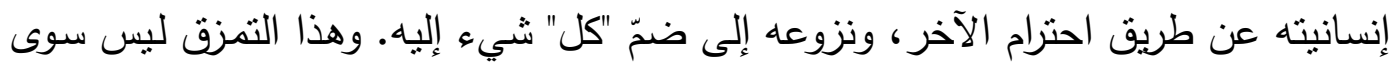

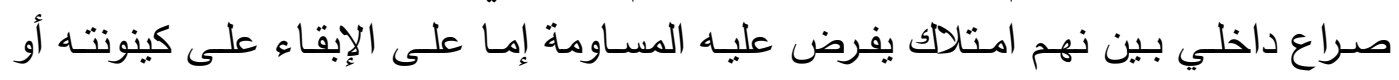

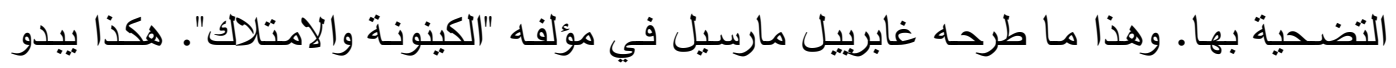

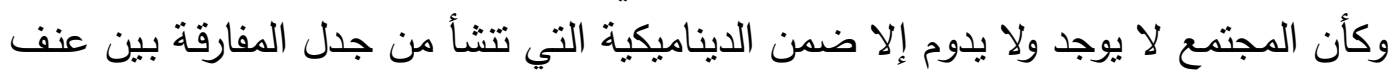

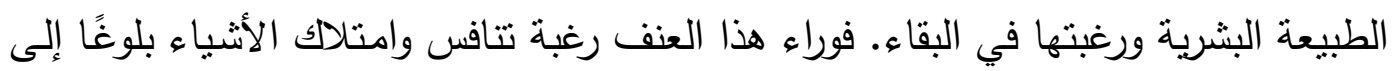

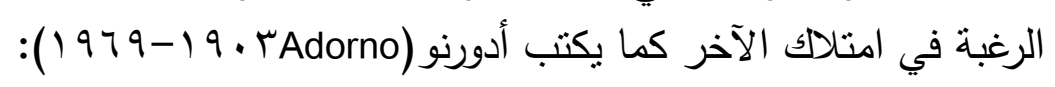

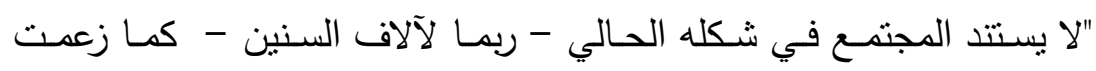

الإيديولوجية منذ أرسطو ، إلى الجاذبية والانجذاب، ولكن إلهابل إلى السعي وراء مصالح

كل واحد على حساب مصالح الآخرين. لقد ترسخت في عمق شخصية الإنسان.

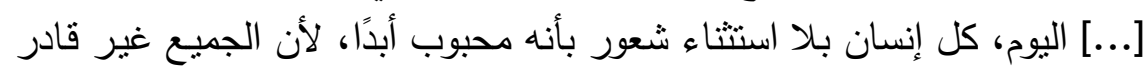

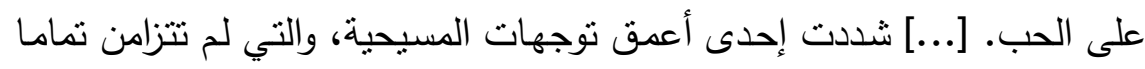

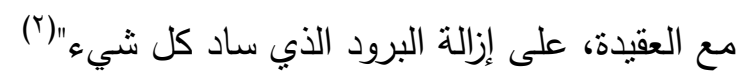

(1) FrançoisHéritier., De la violence II, Opus, Seuil, 1999, Paris.

(2) Theodor W. Adorno, Modèles critiques, Paris, Payot, 1984, p. 216-217. 


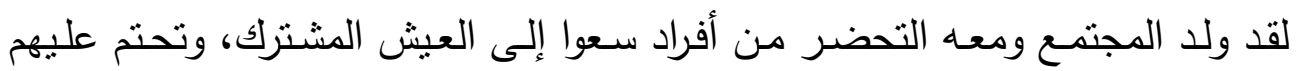

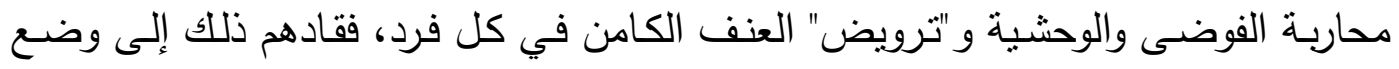

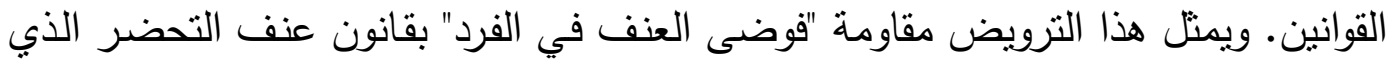

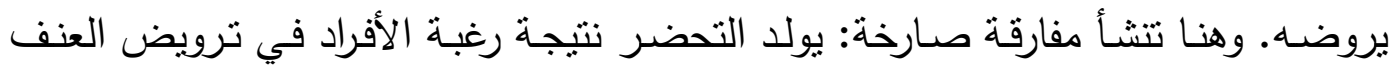

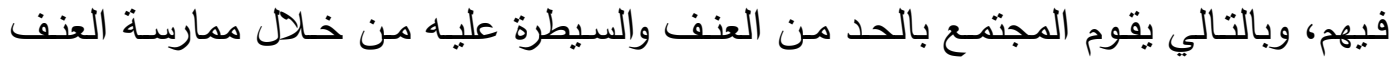

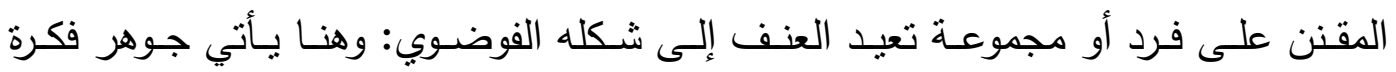

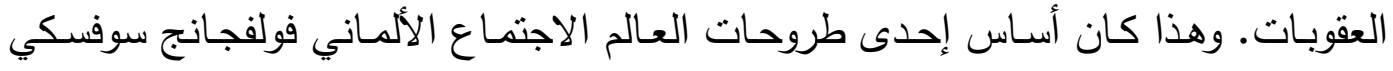

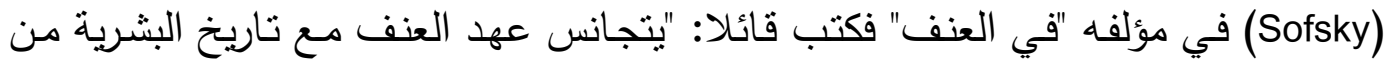

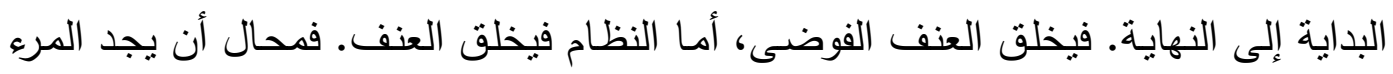

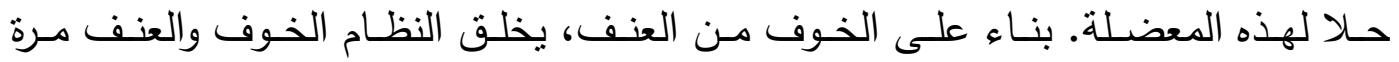

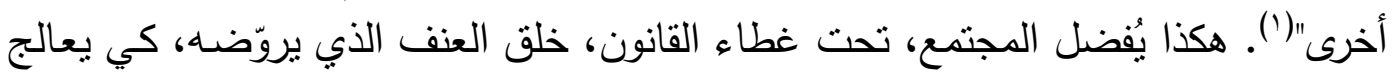

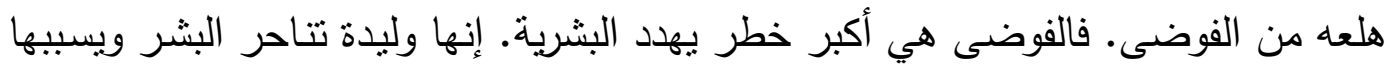

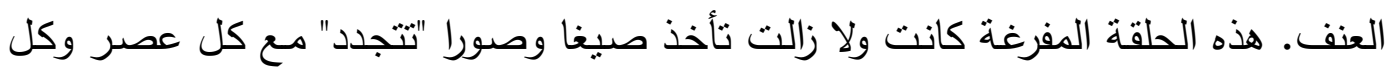

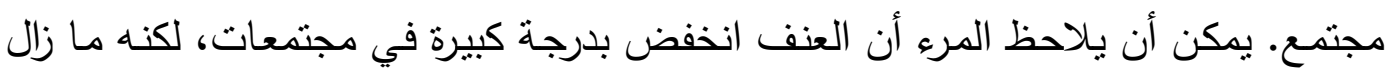

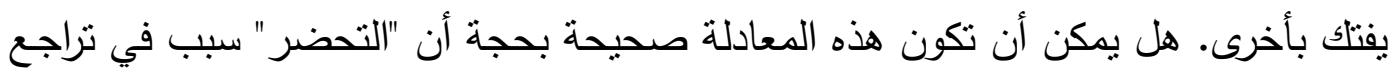
العنف

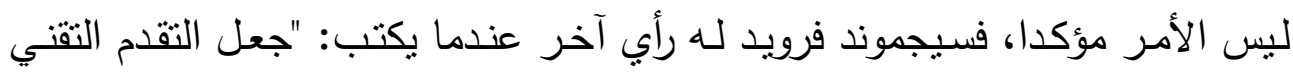

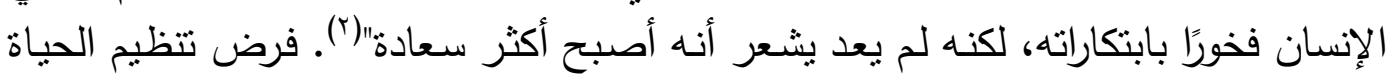

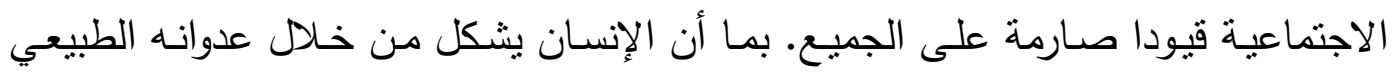

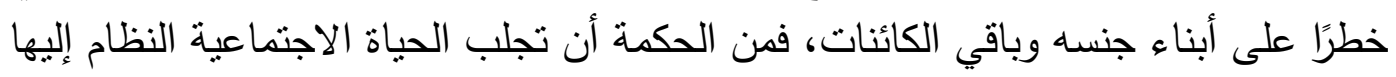

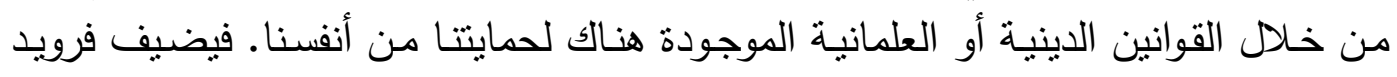

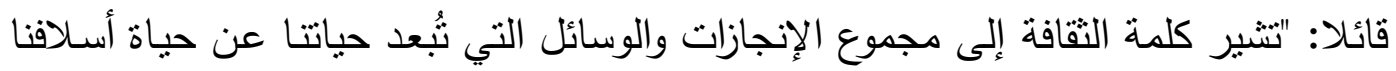

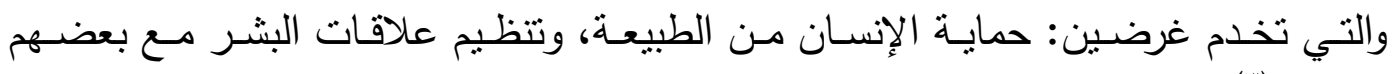

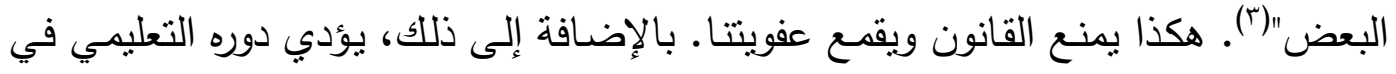

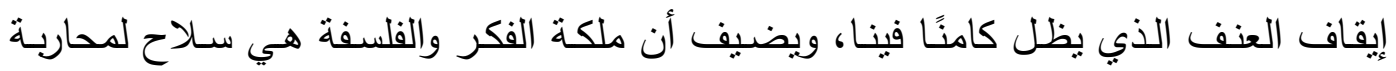

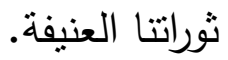

(1) Wolfgang Sofsky, Traité de la violence, Trad. de l'allemand par Bernard Lortholary, Coll., NRF Essais, Gallimard, 1998, p,12.

(2) Sigmund Freud, Malaise dans la civilisation, 1929, PUF, p, 35,

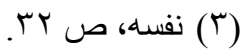




\section{أ. التنافس وشرعية عنف الدولة (ماكس فيبر):}

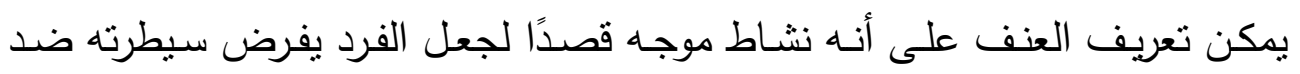

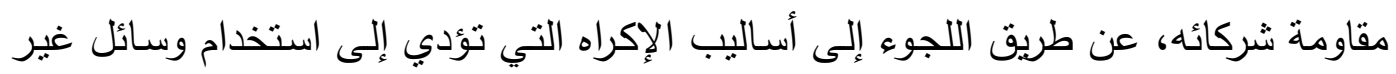

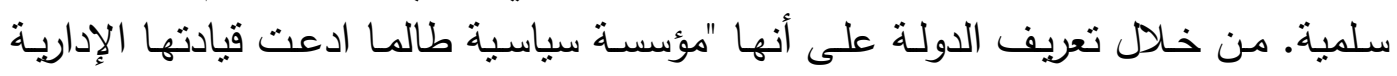

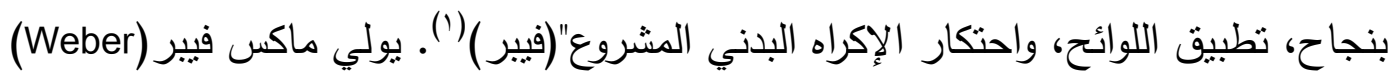

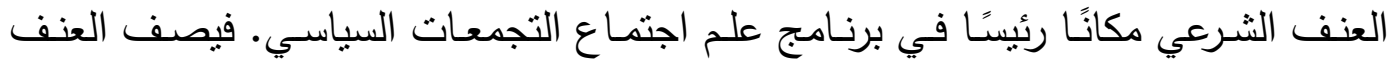
الشرعي وسيلة مقتصرة على الدولة وشرط ضروري". ومع ذللك، وعلى الرغم من هذه الأهمية

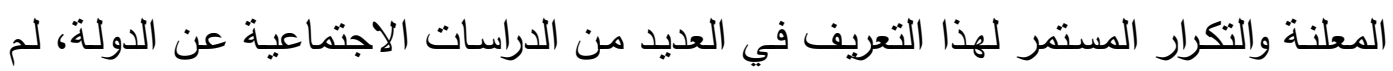
تتلق فكرة العنف المشروع سوى القليل من البحث التجريبي في العلوم الاجتماعية. لماذا هذه

الفجوة؟

يبدو أن الهلع الذي سببه الخوف من الرجوع إلى زمن التتاحر والوحشية قد غطى التى

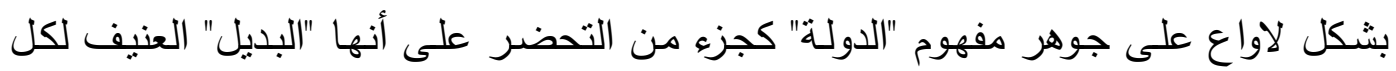
مواطن فيها.فيصبح العنف وسيلة للعمل الاجتماعي (فيبر). فيكمن طابع الدولة الخاص في لهي

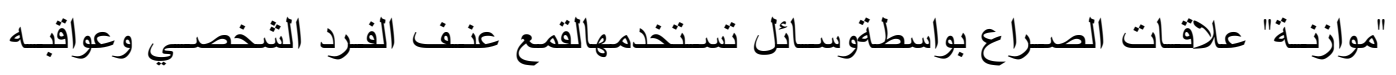
الاجنماعية؛إنها ممارسة هيمنة بواسطة قيود مستترة. وفق فيبر ، يكمن دور الدولة لا في قلع

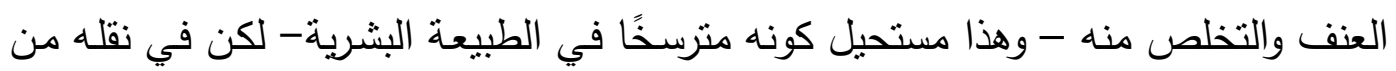

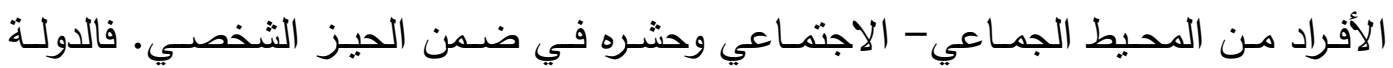

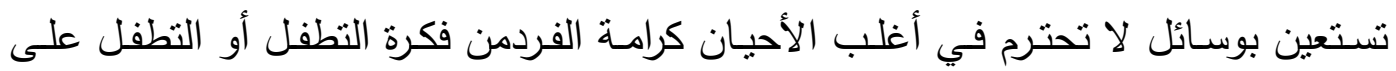
حساب الآخر مثلا، جسديًا أو نفسيًا أو اجتماعيًا.

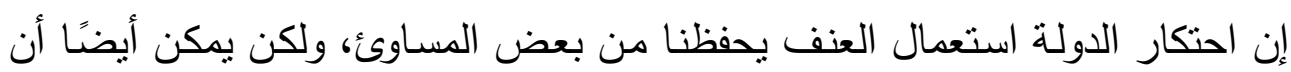

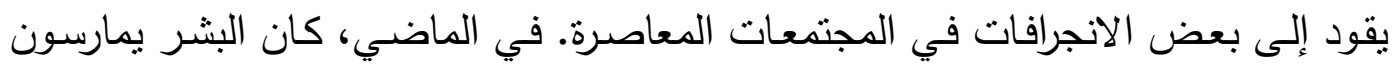

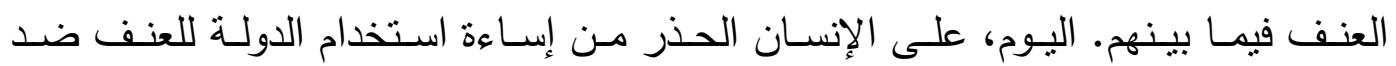

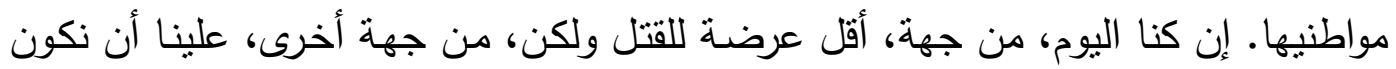
أكثر حرصًا بشأن تزايد الاحتياطات الأمنية للسلطة والرقابة في تقييد حرية الأفراد.

بالنسبة إلى فيبر ، المفارقة واضحة وهي تحدث ضمن جدلية لا مناص منها: تمر كل

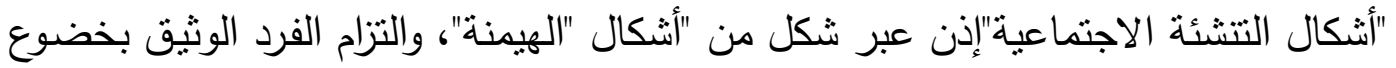

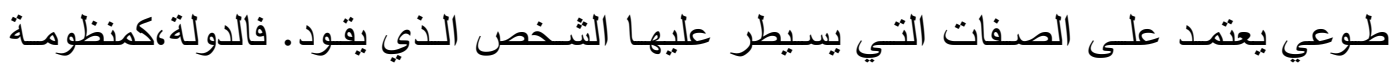

(1) Max Weber, Économie et société, Paris, Plon, 1971, p. 57. 


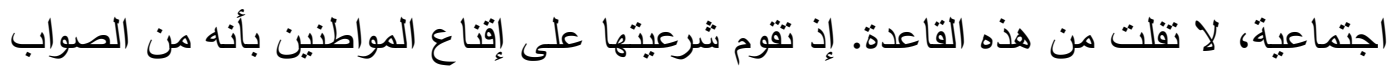

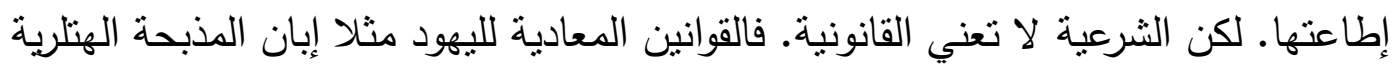

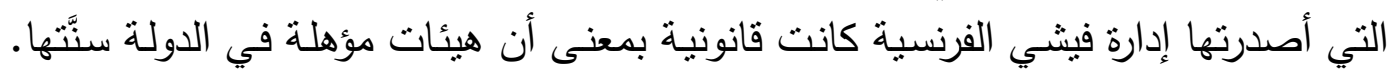

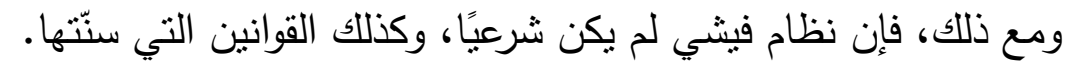

\section{ب. الحضارة، ترويض لاوافع الفرد:}

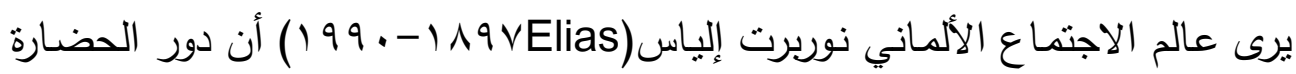

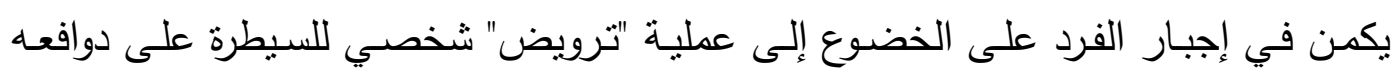

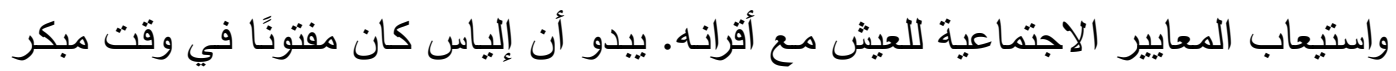

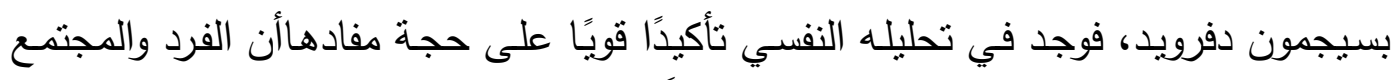

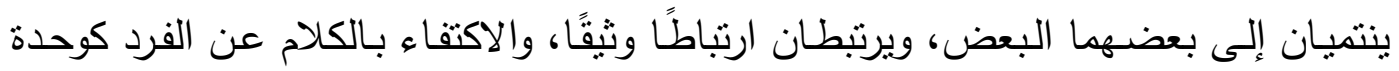

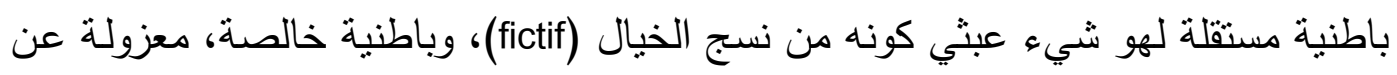

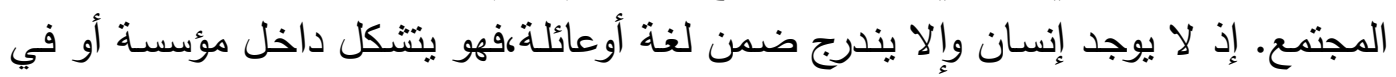

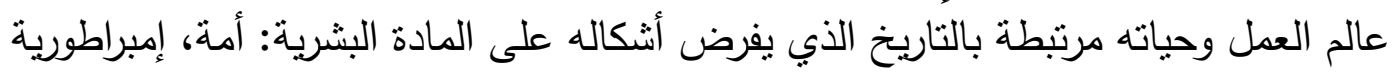
أو ديمقراطية ليبرالية.

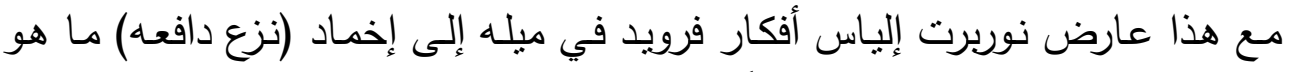

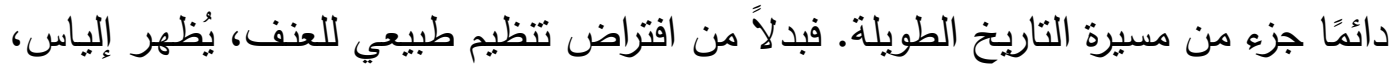

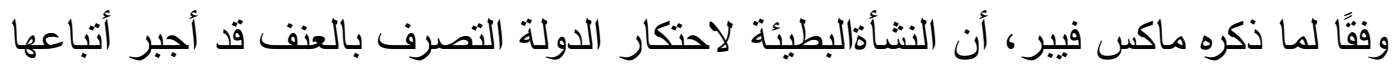

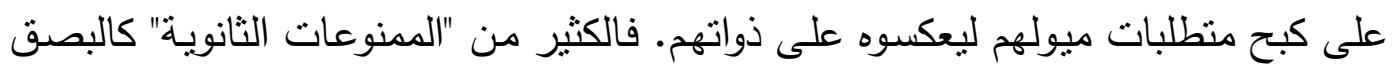

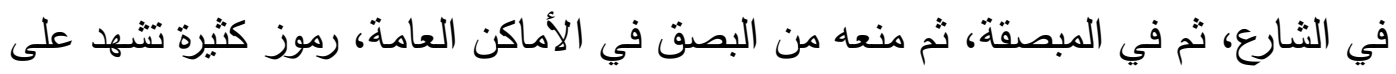

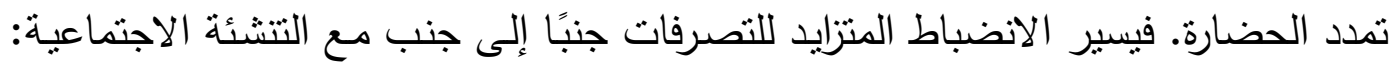
فيظهر العنف في رموزكالتبارز الخطابي، وظهور الحياء الفردي، والاهتمام المتزايد بالطفل والمرأة.

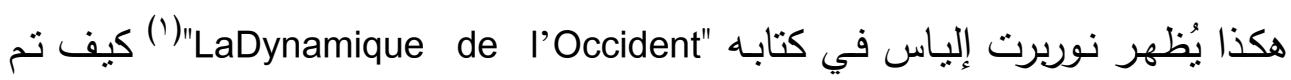

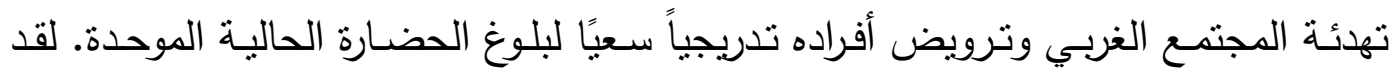

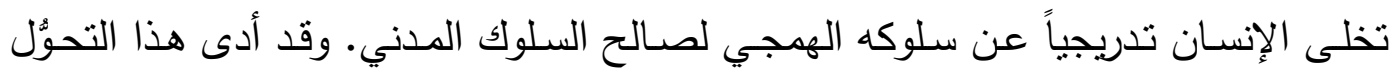

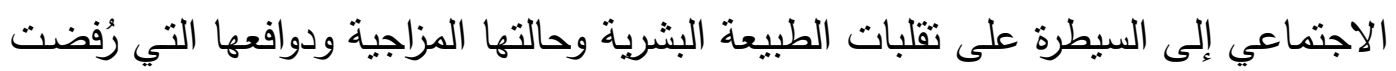

(1) Norbert ELIAS, La dynamique de l'occident, trad. de P.Kamnitzer, Calmann-Lévy, 1975, puis Pocket, coll. Agora, 2003. 
باسم التحضر ، وستختفي ندريجياً من الساحة الاجتماعية لنظل محصورة في المجال الصارم

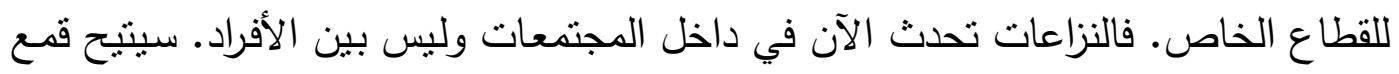

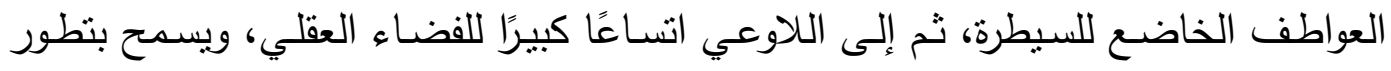

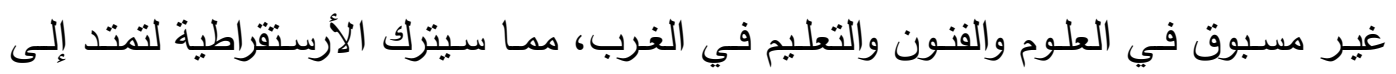
الغالبية العظمى من السكان (')

\section{r. r. مفارقة غياب المعنى في مجتمع متحضر : خيبة الأمل:}

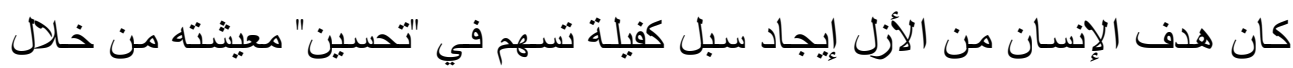

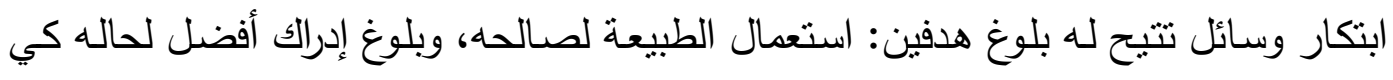

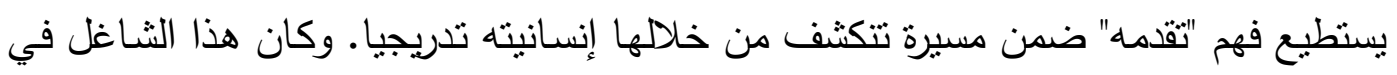

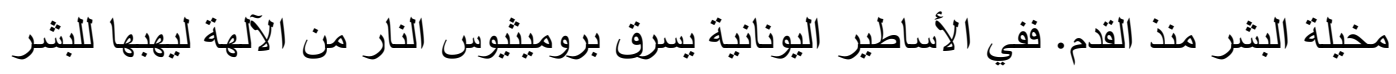

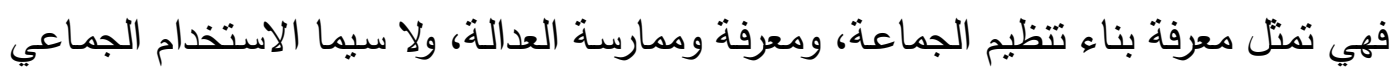

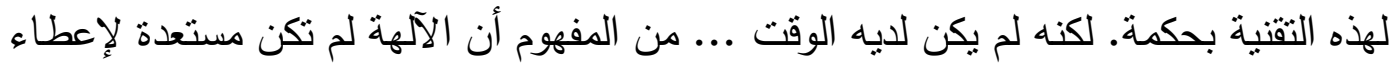

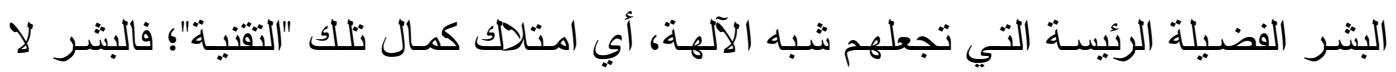

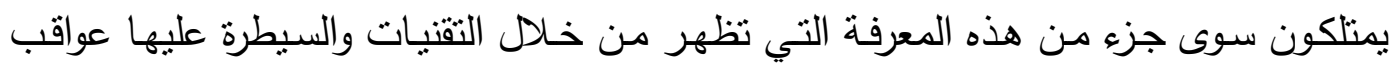

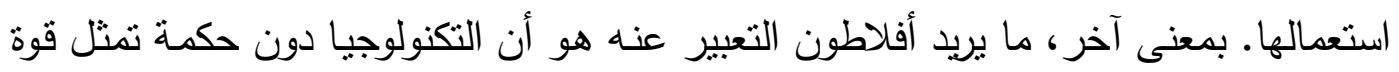

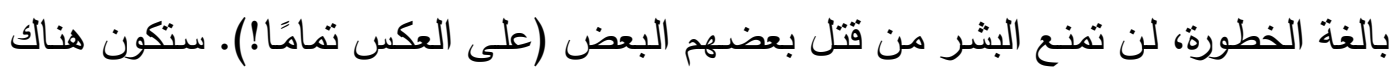

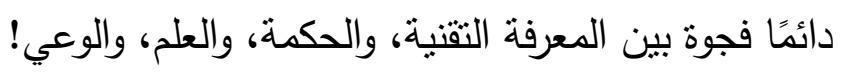

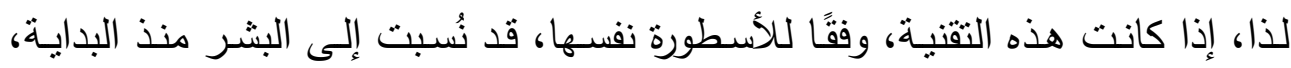

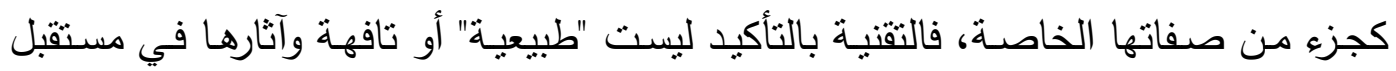

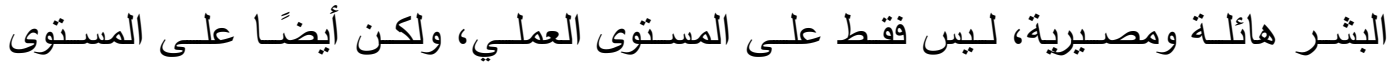

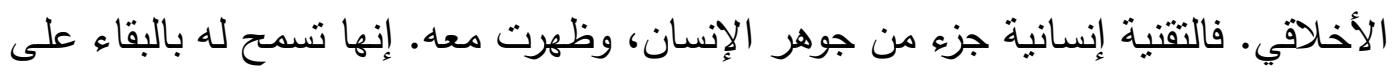

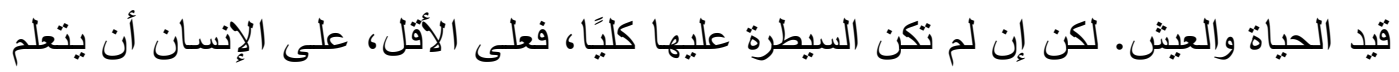

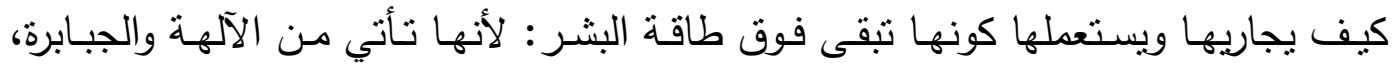

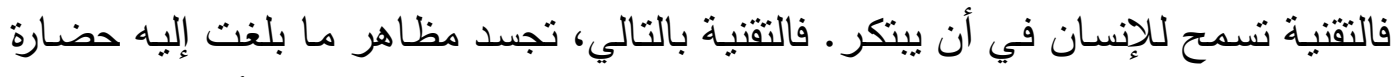
مـا، وتعكس الوسيلة التي بواسطتها تدار مؤسسـات تلأك الحضـارة، ومن أهمها "الدولـة". فالتقنية بذلك جزء جوهري من الحضارة.

(1) André BURGUIERE, Norbert ELIAS, vers une science de l'homme, CNRS, 2004, p. 118 , le concept d'autocontrainte et son usage historique. 


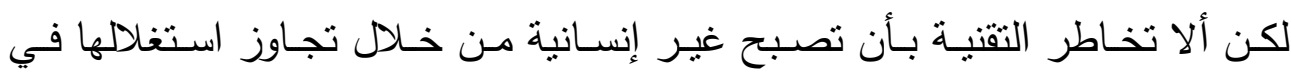
السياسة، والاستخدام غير المنضبط، والخطورة ... إنتاج أشياء مصطنعة عديمة الفائدة ...

فتصبح طريقة تصنيع معززة للقمع، والبحث عن هدف آخر غير الانسان؟

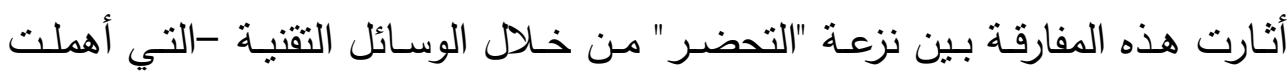

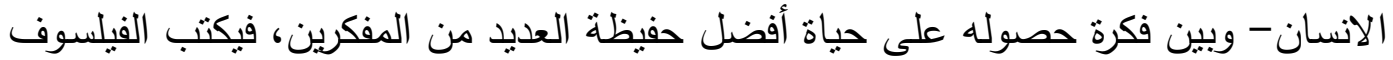

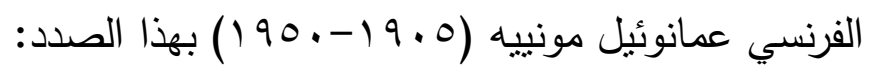

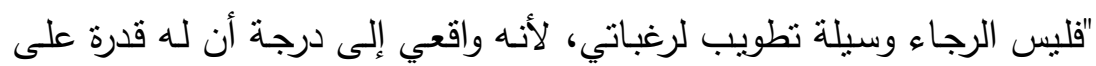

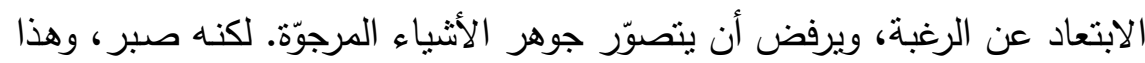

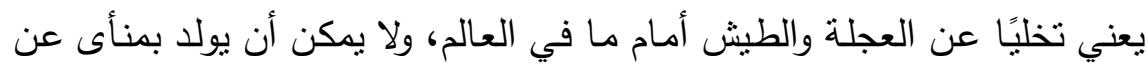

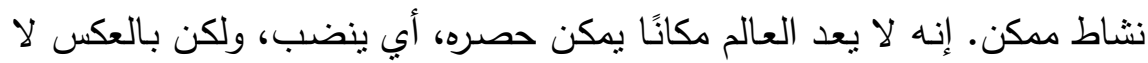
ينضب. إنـه يرفض تكهن الاحتمالات والميل عادة إلى قياس القوى في اللعبـة.

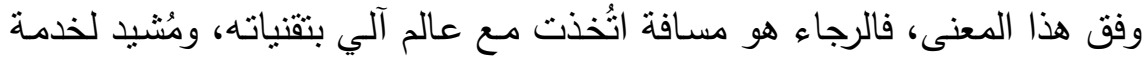

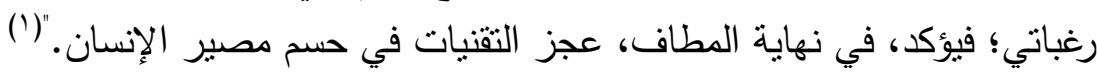
يبدو أن هذا "الطيش" والهوس أمام التقنية قاد لا محالة إلى "لا إنسانية التقنية" التي

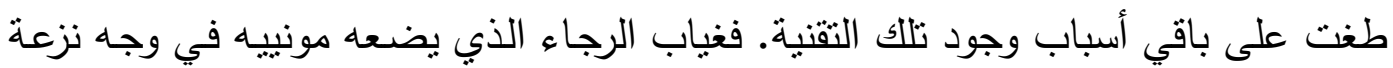

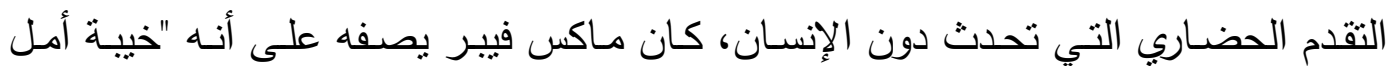
العالم" (le désenchantement du monde) فيكتب قائلا:

"دعونا نجعل فكرة واضحة عما يعنيه الترشيد العملي من خلال العلم والتقنية

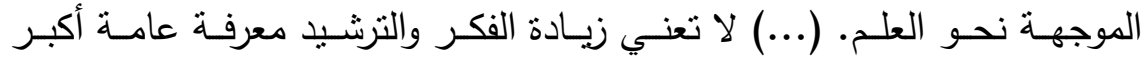

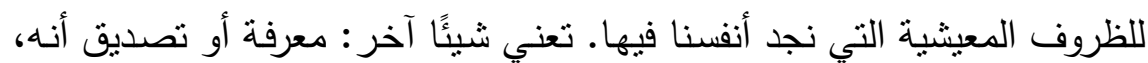

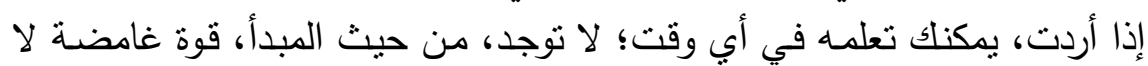

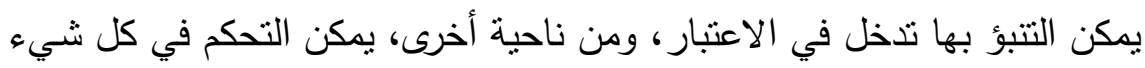

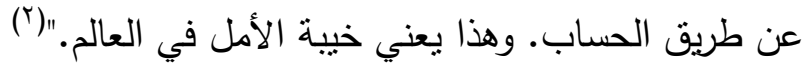
فعالم طغت عليه العقلانية إلى أقصى الحدود، ويمكن أن تجتاحه خيبة الأمل يمكن أن تجناحه في أي لحظة بسبب عدم قدرة الإنسان على السيطرة على "كل" شيء (كامو)،

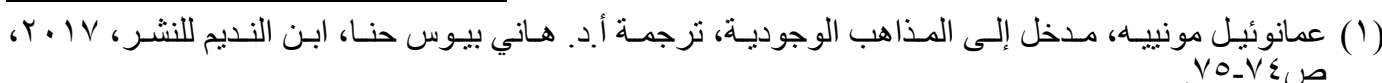

(2) Max Weber, conf. Le savant et le politique, «La profession et la vocation de savant», trad. de Catherine Colliot-Thélène, La Découverte/Poche n 158, 2003, p. 83. 


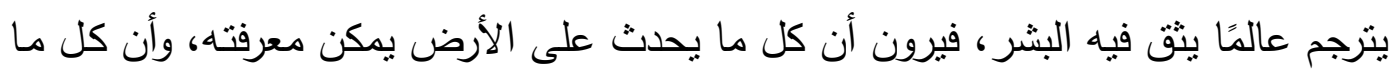

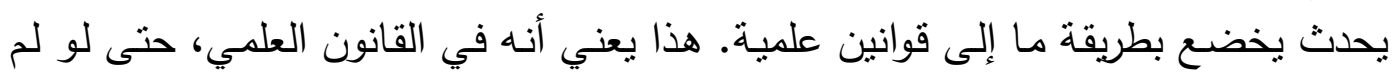

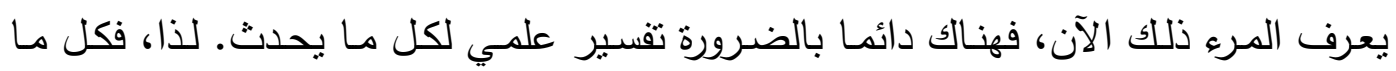

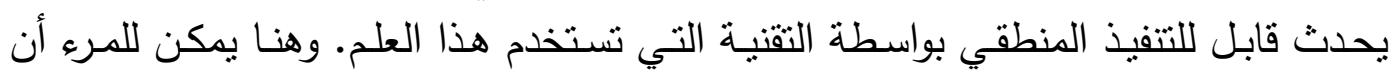

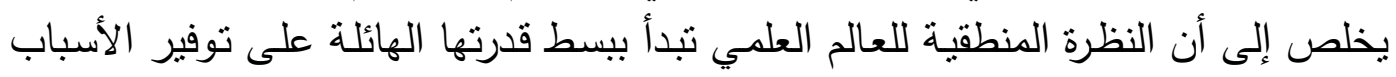

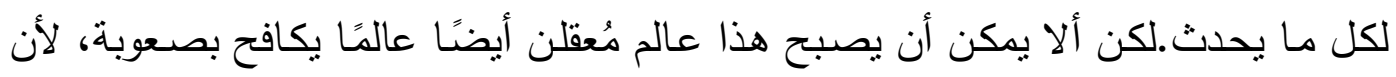

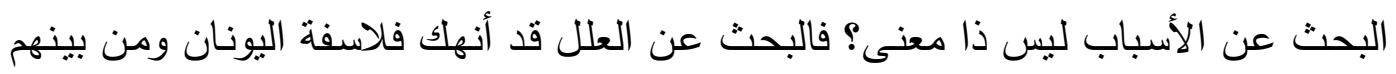

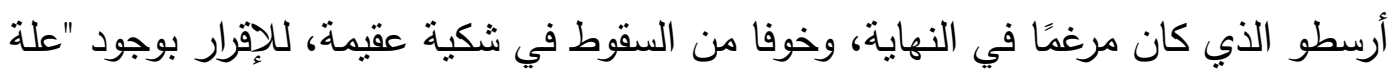

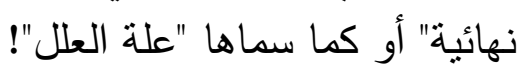

إذا بقينا ضمن الإطار الصسارم الذي يقتضيه التفسير العلمي، فلن نتمكن من العثور

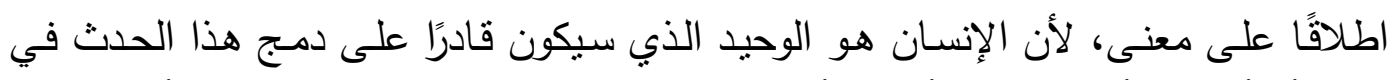

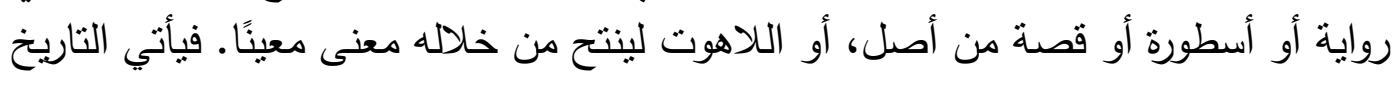
حاضنة للمعنى كونه يُينى على هذه الميادين الفكرية واللاهوتية.

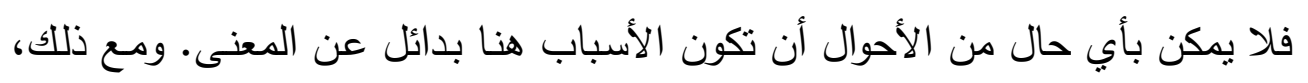

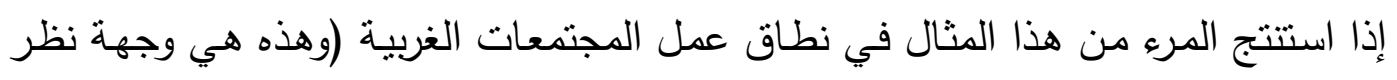

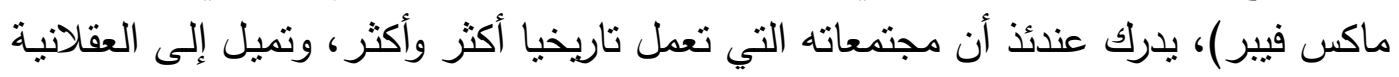

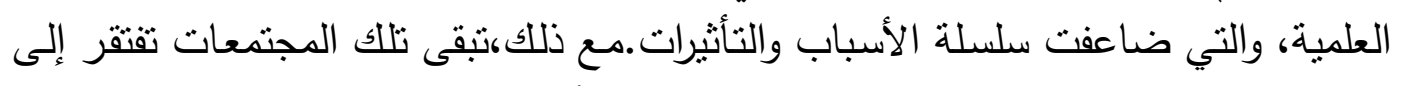

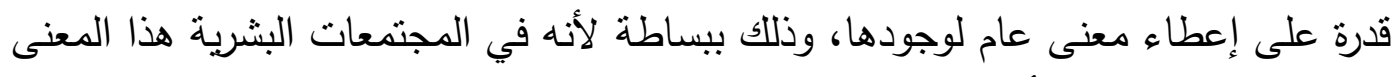

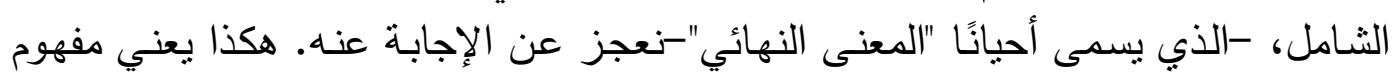

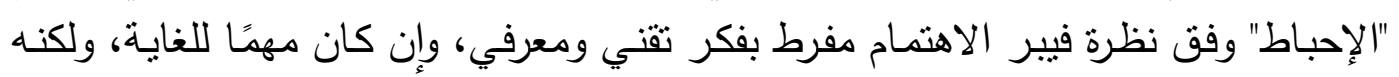
مع ذللك يترك العالم في بحث عن المعنى والفراغ.

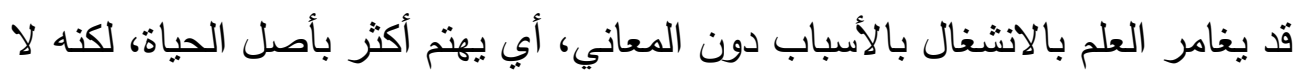

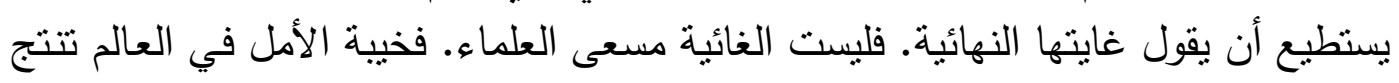

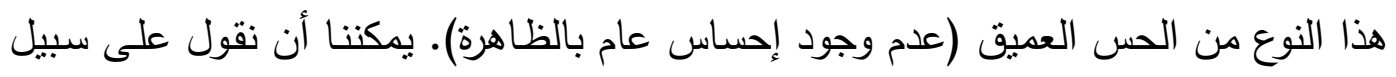

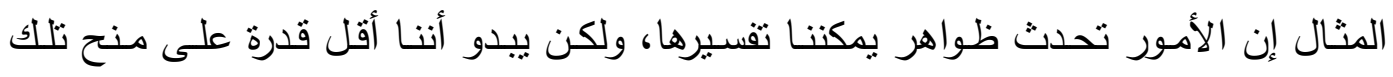

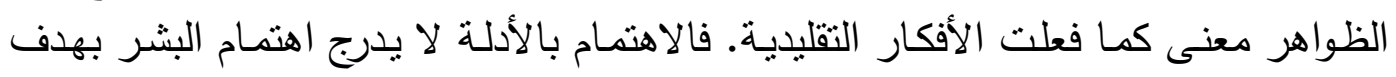

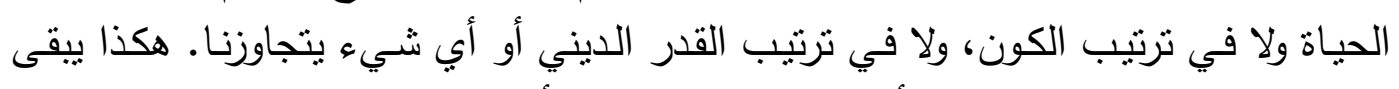

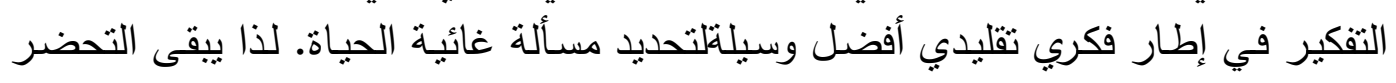


ومعـه القدرة العقلانيـة مفارقة، كون تعليل الظواهر ومنها العنف في المجتمعات المتحضرة

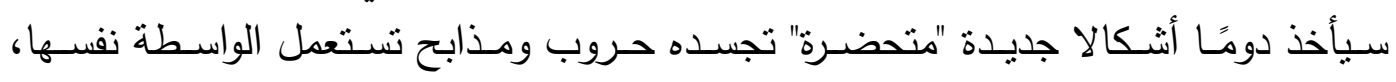

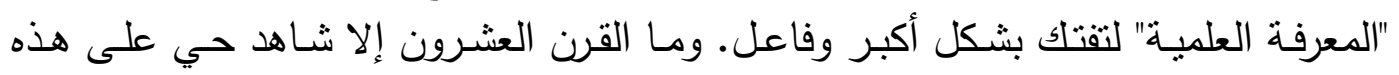

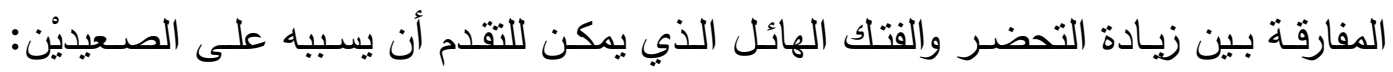
الخارجي، في نزعات بين الشعوب، وداخلي في بناء فردانية تدفع الفرد إلى كبت عنفه تحت سيطرة مجتمعه. 


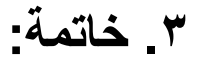

تبقى مفارقة العيش سويًا ضمن عنف منظّم هي التي تدير المجتمعات وتحميها من الني

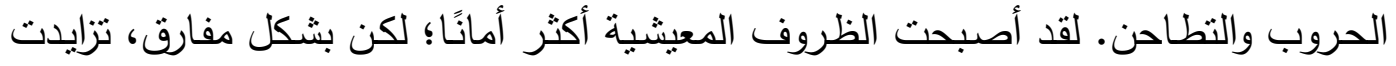

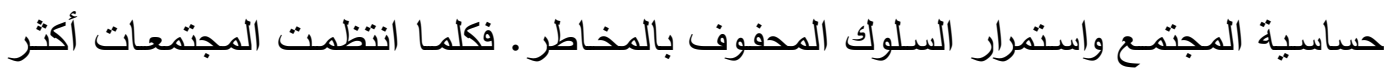

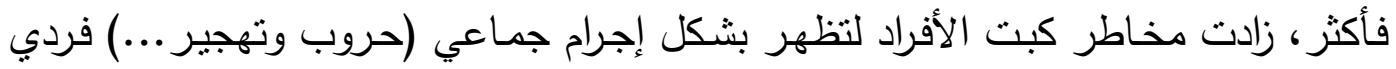

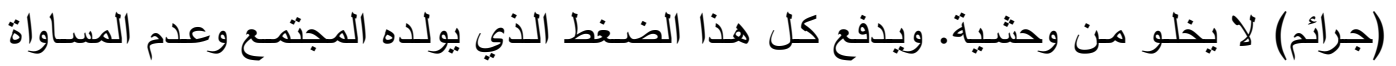
المعيثي العديدين إلى "الانفجار ".

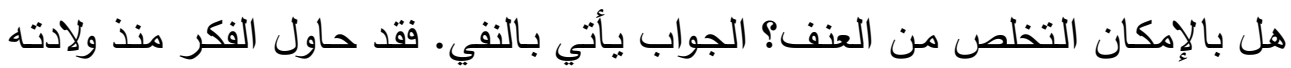

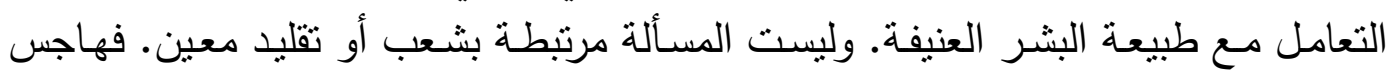

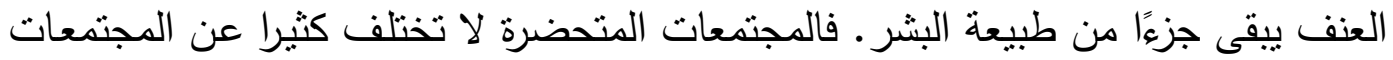

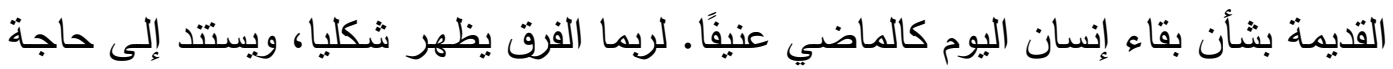

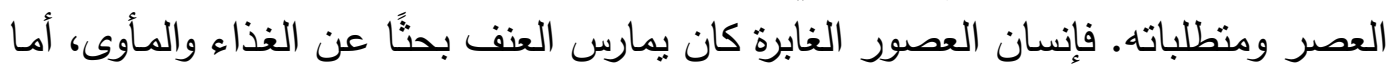

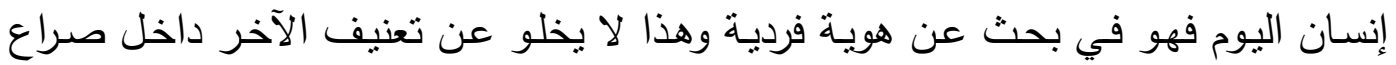

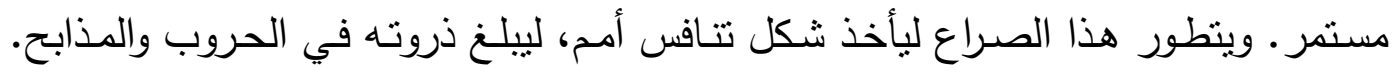

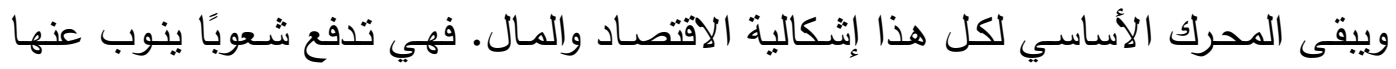

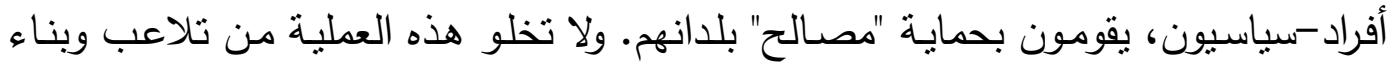

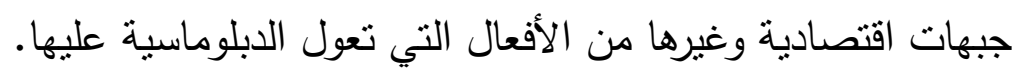

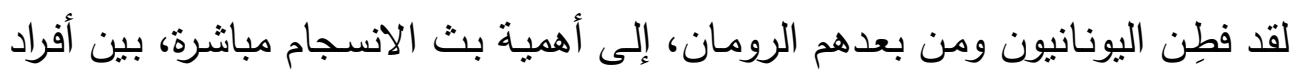

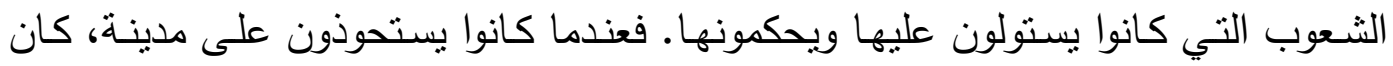

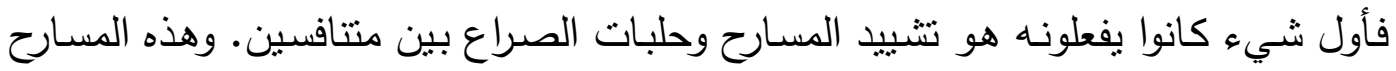

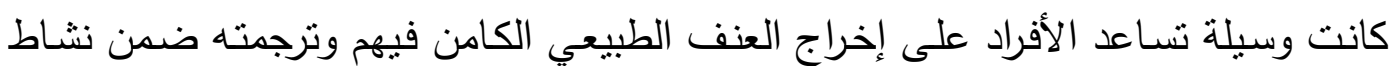

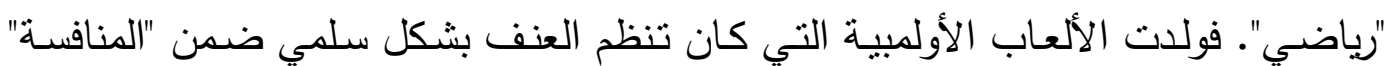

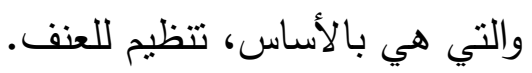




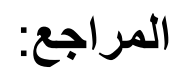

- ClaudeLévi-Strauss, Race et Histoire, collection Médiations, Éd. Denoël-Gonthier, 1968.

- François Héritier., De la Violence II, Opus, Seuil, 1999, Paris.

- Theodor W. Adorno, Modèles Critiques, Paris, Payot, 1984.

- Wolfgang Sofsky, Traité de la Violence, Trad. de l'allemand par Bernard Lortholary, Coll., NRF Essais, Gallimard, 1998.

- Sigmund Freud, Malaise dans la Civilisation, PUF, 1929.

- Max Weber, Économie et Société, Paris, Plon, 1971.

- Norbert ELIAS, La Dynamique de L'Occident, trad. d P.Kamnitzer, Calmann-Lévy, 1975, puis Pocket, coll. Agora, 2003.

- André BURGUIERE, Norbert ELIAS, Vers une Science de L'Homme, CNRS, 2004, le concept d'autocontrainte et son usage historique.

- Max Weber, conf. Le Savant et le Politique, «La profession et la vocation de savant $»$, trad. de Catherine Colliot-Thélène, La Découverte/Poche n ${ }^{\circ} 158,2003$.

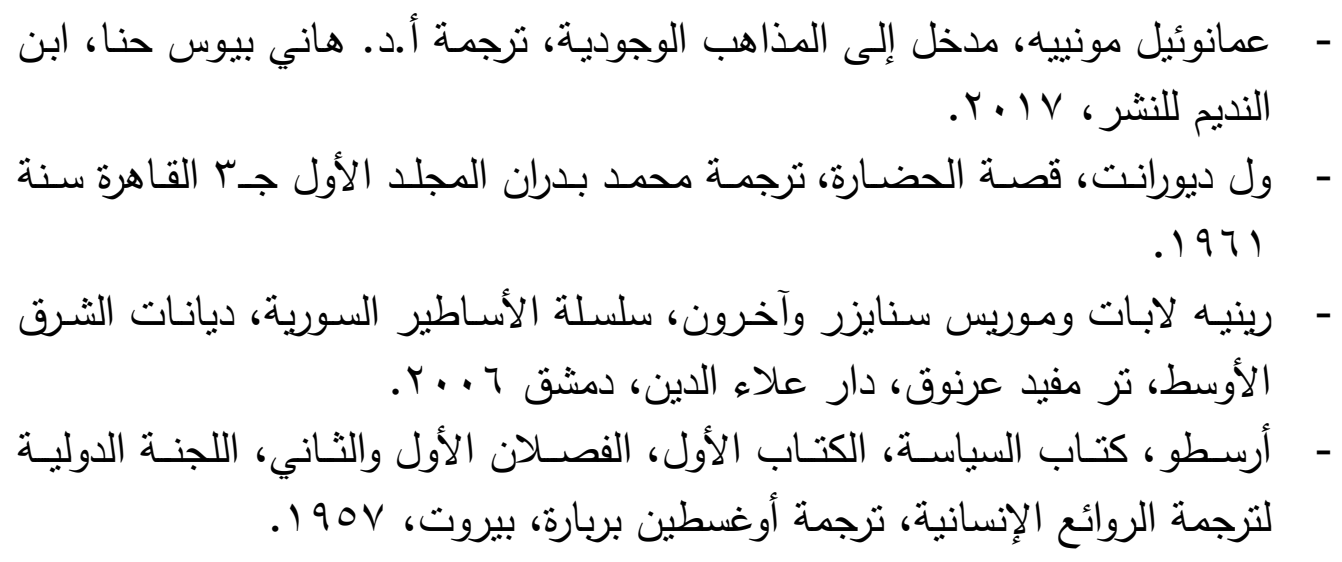

